\title{
Turkish Adaptation of Instrument for Assessing Undergraduate Students' Perceptions of Faculty Knowledge in Technology-Supported Class Environments
}

\author{
Selma ŞENEL*a, Bülent PEKDAĞ ${ }^{\mathrm{b}}$, Mustafa Tuncay SARITAŞ ${ }^{\mathrm{c}}$
}

\begin{tabular}{l} 
Article Info \\
\hline DOI: $10.14686 /$ buefad.363938 \\
\hline Article History: \\
Received $\quad 08.12 .2017$ \\
Revised $\quad 15.01 .2018$ \\
Accepted $\quad 30.01 .2018$ \\
\hline Keywords: \\
Technological pedagogical \\
content knowledge (TPACK), \\
Student perceptions, \\
Instrument adaptation, \\
Learning environments \\
\hline Article Type: \\
Research Article
\end{tabular}

\begin{abstract}
This study is aimed at adapting an instrument for "Assessing College Students' Perceptions of Faculty Knowledge in Technology-Supported Class Environments" developed by Shih and Chuang (2013) into Turkish by conducting validity and reliability procedures. This study is crucial due to the fact that it focuses on how students perceive teacher's knowledge in technology-supported classrooms. The adaptation procedure has such stages as (i) translation, (ii) back translation, (iii) experts' opinion, (iv) pilot assessment to 25 students and final modification, and (v) implementation of the instrument to 430 undergraduate students for validity and reliability studies. For construct validity, confirmatory factor analysis was done. The results showed medium and high goodness-of-fit indices $(\chi 2 / \mathrm{df}=3.94$, RMSEA $=0.083$, NFI $=0.91$, NNFI $=0.93, \mathrm{CFI}=0.94, \mathrm{RMR}=0.074)$. In terms of the reliability, Cronbach's alpha reliability coefficient is found to be 0.945 ; Spearman Brown reliability coefficient is 0.742 ; and Guttmann split-half reliability coefficient is 0.725 . These results showed evidence for a high internal reliability for the instrument. Like the original version of the instrument, Turkish adaptation has also 4 constructs including a total of 50 items.
\end{abstract}

\section{Öğretim Elemanlarının Teknoloji Destekli Sınıflardaki Yeterliklerine İlişkin Öğrenci Algıları Ölçeğinin Türkçeye Uyarlanması}

\begin{tabular}{|c|c|}
\hline \multicolumn{2}{|c|}{ Makale Bilgisi } \\
\hline \multicolumn{2}{|c|}{ DOI: 10.14686/buefad.363938 } \\
\hline \multicolumn{2}{|c|}{ Makale Geçmisisi: } \\
\hline Geliş & 08.12 .2018 \\
\hline Düzeltme & 15.01 .2018 \\
\hline Kabul & 30.01 .2018 \\
\hline \multirow{6}{*}{\multicolumn{2}{|c|}{$\begin{array}{l}\text { Anahtar Kelimeler: } \\
\text { Teknolojik pedagojik alan } \\
\text { bilgisi (TPACK), } \\
\text { Öggrenci algıları, } \\
\text { Ölçek uyarlama, } \\
\text { Öğrenme ortamı }\end{array}$}} \\
\hline & \\
\hline & \\
\hline & \\
\hline & \\
\hline & \\
\hline \multicolumn{2}{|c|}{ Makale Türü: } \\
\hline Araştırma & alesi \\
\hline
\end{tabular}

Öz

Bu araştırmada, Shih ve Chuang (2013) tarafından geliştirilen "Öğretim Elemanlarının Teknoloji Destekli Sınıflardaki Bilgilerine İlişskin Öğrenci Algıları Ölçeği”nin Türkçeye uyarlanarak, geçerlik ve güvenirlik çalışmalarının yapılması amaçlanmıştır. Türkçeye uyarlanan ölçeğin, öğretim elemanlarının teknoloji destekli sınıflardaki bilgisinin öğrenciler tarafından nasıl algılandığı üzerine odaklanması çalışmanın önemini ortaya koymaktadır. Çalışma kapsamında; (i) çeviri, (ii) geri çeviri, (iii) uzman görüşü, (iv) 25 kişilik bir öğrenci grubuna ilk uygulama ve son inceleme aşamalarından geçirilerek oluşturulan ölçeğin uyarlama formu; (v) geçerlik ve güvenirlik incelemeleri için 430 üniversite öğrencisinden oluşan çalışma grubuna uygulanmıştır. Yapı geçerliğini incelemek amacıyla doğrulayıcı faktör analizi yapılmıştır. Analiz sonucunda iyi uyum değerleri elde edilm/iştir $\left(\chi^{2} / \mathrm{sd}=3.94\right.$, RMSEA=0.083, NFI=0.91, NNFI=0.93, CFI=0.94, RMR=0.074). Cronbach alfa güvenirlik katsayıs1 0.945, Spearman Brown güvenirlik katsayıs1 0.742 ve Guttmann iki yarı güvenirlik katsayıs1 0.725 olarak bulunmuştur. Bu sonuçlar, uyarlanan ölçeğin iç tutarlılığının yüksek olduğunu ortaya koymuştur. Türkçeye uyarlanan ölçeğin, orijinal ölçekteki gibi 4 alt boyuta sahip olduğu ve toplam 50 maddeden oluştuğu gözlenmiştir.

\footnotetext{
*Corresponding Author: selmahocuk@gmail.com

${ }^{a}$ Dr., Balıkesir University, Balıkesir/Turkey, https://orcid.org/0000-0002-5803-0793

b Assoc. Prof. Dr., Balıkesir University, Balıkesir/Turkey, https://orcid.org/0000-0003-0611-0617

c Assoc. Prof. Dr., Balıkesir University, Balıkesir/Turkey, https://orcid.org/0000-0001-6956-9519
} 


\section{Introduction}

With rapid advance in technology and its increasing use in various sectors (e.g., education, security, medicine, agriculture, transportation, etc.), technology has promptly become a norm that shapes our daily life. As in all other fields, the emerging technology in education sector has provided new learning environments in which instruction and technology are intertwined (Arkorful \& Abaidoo, 2014; Preston et al., 2015; Rabah, 2015). Technologysupported teaching and learning resources and methods have become a common use in higher education for a better instruction (Bennett, Bishop, Dalgarno, Waycott \& Kennedy, 2012; Çakır, 2013; Manca \& Ranieri, 2016; Merchant, Goetz, Cifuentes, Keeney-Kennicutt \& Davis, 2014). In particular, technology-supported learning environments along with new software and hardware systems are considered to be solutions for a variety of educational problems caused by techno-social life (Hew, 2016; Hsu, Hwang, Chuang \& Chang, 2012; Tüzün \& Özdinç, 2016; Yu \& Wu, 2016). Though, it is not the case in terms of one type of technology used in learning environments but it is primarily related with how technology is effectively integrated in those environments (Aksoy, 2003; Campbell \& Abd-Hamid, 2013; Pekdağ, 2010). In extensive use of technology in education, the scholars have pointed out the idea that pedagogical knowledge and content knowledge are simply inadequate to be able to integrate technology in a learning environment. Technological knowledge, in this matter, is commonly suggested in the literature to be another knowledge for technology integration. Technology integration necessitates knowledge of technology, pedagogy, and content altogether, which are considered as a must-to-have for teachers' professional development (Angeli \& Valanides, 2009; Campbell \& Abd-Hamid, 2013; Koehler, Mishra \& Yahya, 2007; Mishra \& Koehler, 2006; Pamuk, 2012; Pekdağ, 2015). Hence, it has become evident in many recent research studies and reports that technological pedagogical content knowledge (i.e., TPACK) has gained an important place as a new type of knowledge (Allan, Erickson, Brookhouse \& Johnson, 2010; Chen \& Jang, 2014; Graham et al., 2009; Hao, 2016; Lee \& Tsai, 2010; Öztürk, 2013; Polly, 2011).

This type of knowledge (i.e., TPACK) is stated as a vital competence for teachers in "National Teacher Strategy Document" in Turkey in 2013. The document, under the title - Improvement of Pre-service Teacher Training, puts a considerable emphasis on the concept of TPACK including interdisciplinary and integrated instructional programs replacing the concept of pedagogical training alone (MEB, 2013). The report called "Teacher Competencies" prepared by Turkish Education Association also includes TPACK and describes it as "to be knowledgeable about instructional programs and subject-matter curriculum; teaching methods; interdisciplinary relations; new developments, fundamental concepts, instructional tools and structures of the subject area; and technology integration into teaching content" (TED, 2009, p.7). Additionally, the Scientific and Technological Research Council of Turkey financially supports the research studies and in-service training programs and workshops, which enable teachers to obtain technological-pedagogical-content knowledge (Canbazoğlu Bilici, 2013). Technological, pedagogical, and content knowledge are all considered as fundamental interconnected elements for teachers' professional development.

\section{Technological Pedagogical Content Knowledge (TPACK)}

Shulman (1987) descibes teachers' professional knowledge as it consists of pedagogical knowledge, content knowledge, and thus pedagogical content knowledge. The researchers (Angeli \& Valanides, 2005; Mishra \& Koehler, 2006; Niess, 2005) insistently indicate a need for developing a new body of knowledge that constitutes an extension of Shulman's (1987) pedagogical content knowledge (PCK) into the domain of teaching with technology. Mishra and Koehler (2006) proposed technological knowledge in addition to PCK, which becomes technological pedagogical content knowledge. TPACK presents a new theoretical framework (see Fig. 1) focusing the interplay of different types of knowledge necessary for teachers (Koehler et al, 2007).

The TPACK framework introduces the relationships between three knowledge domains (technology, pedagogy, and content). Seven knowledge categories in the TPACK framework are derived from those domains (see Figure 1). The knowledge categories are defined as follows:

1. Technology Knowledge (TK), "the knowledge and skills of various traditional, current, and emerging technologies" (Chen \& Jang, 2014, p.81) or "the knowledge about technology literacy, and its integration and utilization in learning contexts" (Öztürk \& Horzum, 2011, p.257); 
2. Content Knowledge (CK), "the knowledge about actual subject matter that is to be learned or taught" (Mishra \& Koehler, 2006, p.1026);

3. Pedagogical Knowledge (PK), "the knowledge about methods and process of teaching, such as classroom management, assessment, lesson plan development, and student teaching” (Schmidt et al., 2009, p.125);

4. Pedagogical Content Knowledge (PCK), "the tacit of blending content and pedagogy for developing better teaching practices" (Chen \& Jang, 2014, p.81);

5. Technological Content Knowledge (TCK), "the knowledge of media selection and transforming/representing subject matter using those technological vehicles" (Chen \& Jang, 2014, p.81) or "the knowledge of how technology can create new representations for specific content" (Schmidt et al., 2009, p.125);

6. Technological Pedagogical Knowledge (TPK), "the knowledge of the affordances of technologies and what teaching strategies can be combined with those affordances to leverage learning outcomes" (Chen \& Jang, 2014, p.81) or "the knowledge of how various technologies can be used in teaching" (Schmidt et al., 2009, p.125);

7. Technological Pedagogical Content Knowledge (TPACK), “teachers' understanding of the interplay among content, pedagogy, and technology, as well as the procedural knowledge of integrating technologies into their teaching routines" (Chen \& Jang, 2014, p.81) or "the knowledge required by teachers for integrating technology into their teaching in any content area" (Schmidt et al., 2009, p.125).

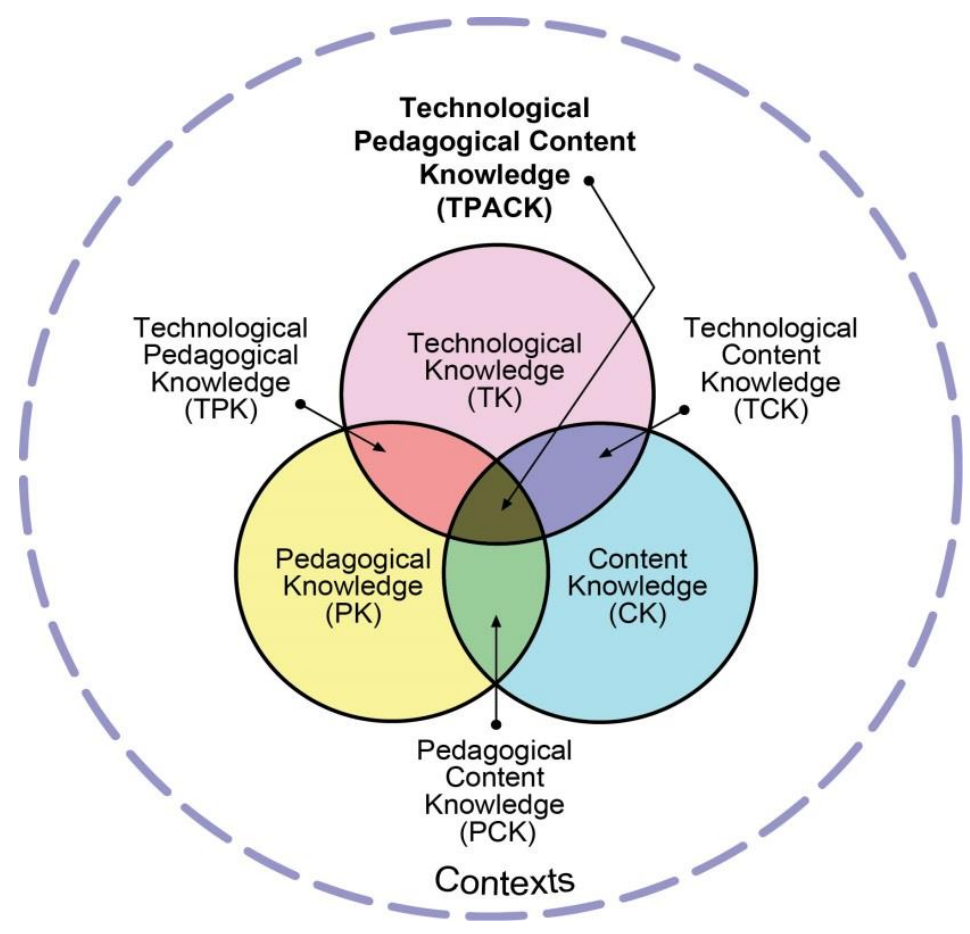

Figure 1. The TPACK Framework (Koehler \& Mishra, 2012)

Effective technology integration for teaching a subject-matter requires not only knowledge of content, technology and pedagogy, but also knowledge of their relationships to each other. Koehler et al. (2007) pointed out that "at the heart of TPACK is the dynamic, transactional relationship between content, pedagogy and technology. Good teaching with technology requires understanding the mutually reinforcing relationships between all three elements taken together to develop appropriate, context-specific strategies and representations" (p.741). 
The TPACK is offered as a framework for revitalizing teachers' knowledge as well as for collecting and organizing data on teacher cognition about technology integration. Angeli and Valanides (2009, pp.163-164) proposed 5 criteria for assessing the TPACK:

1. Identification of topics to be taught with technology in ways that signify the added value of tools, such as, topics that students cannot easily comprehend, or topics that teachers face difficulties in teaching them effectively in class;

2. Identification of representations for transforming the content to be taught into forms that are comprehensible to learners and difficult to be supported by traditional means;

3. Identification of teaching strategies, which are difficult or impossible to be implemented with traditional means;

4. Selection of appropriate ICT tools and effective pedagogical uses of tool affordances;

5. Identification of appropriate strategies for the infusion of technology in the classroom, which includes any strategy that puts the learner at the center of the learning process to express a point of view, observe, explore, inquire, and in general, problem solve.

The TPACK framework provides "an analytic lens or instrument to study categories of teachers' knowledge" (Chen \& Jang, 2014, p.79). The TPACK framework focuses on evaluating teacher knowledge that is crucial for successful student learning in many areas (Schmidt et al., 2009).

\section{Purpose of the Study}

Based on TPACK framework suggested by Mishra and Koehler (2006), a number of research instruments and/or scales has been developed and extensively conducted in the literature. Schmidt et al. (2009) developed and validated an instrument designed to measure pre-service teachers' development of TPACK. The instrument contained 75 items for measuring preservice teachers' self-assessments of the seven knowledge domains within the TPACK framework including 8 TK items, 17 CK items, 10 PK items, 8 PCK items, 8 TCK items, 15 TPK items, and 9 TPACK items. This instrument was adapted into Turkish by Öztürk \& Horzum (2011), Kaya and Dağ (2013), and Kaya, Kaya and Emre (2013).

Graham et al. (2009) developed a TPACK scale consisting of 4 factors (TK, TPK, TCK, and TPACK) with the purpose of determining the self-confidence of science education teachers on TPACK. This scale was adapted into Turkish by Timur and Taşar (2011). Moreover, Archambault and Crippen (2009) used a survey instrument including 24 items designed to measure K-12 online distance teachers' knowledge domains as described by the TPACK framework. Another scale by Lee and Tsai (2010) was developed to scrutinize Taiwanese teachers' selfefficacy and TPACK level in educational use of World Wide Web.

Numerous measurement and evaluation instruments and scales related to the TPACK were conducted to investigate the existing knowledge and perceptions of teachers and teacher candidates with regards to technologysupported instruction. In many of these studies, teachers or teacher candidates were predominantly recruited and surveyed to determine their individual level of TPACK (Akgün, 2013; Kaya \& Dağ, 2013; Kaya, Kaya, \& Emre, 2013; Öztürk, 2013; Öztürk \& Horzum, 2011). There are relatively limited studies recruiting students (as key actors of instruction), which examine how students develop perceptions about their teacher's knowledge and instruction in technology-supported learning environments (Lee, 2011; Shih \& Chuang, 2013).

Studies regarding learning environments are mostly based on learner cognition that accentuates learners' perceptions and the way they react to learning tasks. According to this view, it is of greater importance that the quality of classroom instruction perceived by students than the quality of observed teaching behaviors by students (Knight \& Waxman, 1991). Some studies report that research need to be done especially in relation with students' perceptions about their teacher's knowledge. In order to improve the quality of instruction, further studies have been suggested to investigate how students perceive the task of teaching (Knight \& Waxman, 1991; Tuan, Chang, 
Wang \& Treagust, 2000). Hence, it is crucial to know how students perceive their teacher's competence in providing an effective instruction using technology.

There is a need for an instrument that examines the level of knowledge of faculty members in technologysupported classrooms through student perceptions in Turkish contexts. With this purpose in mind, an adaptation of an instrument in Turkish along with reliability and validity processes is considered to contribute to the other studies in the field. An instrument for a psychological measurement developed for a specific culture can also be used for different cultures and languages. An adaptation process of an instrument can be defined as a process about not only translating the items in a different language but also conducting fundamental psychometric processes according to a specific culture (Deniz, 2007). This study aimed at adapting an instrument by Shih \& Chuang (2013) for assessing undergraduate students' perceptions of faculty knowledge in technology-supported learning environments into Turkish sampling.

\section{Method}

\section{Participants}

The sample of the study consists of 469 undergraduate students studying in four different faculties of a state university. The average student age is 21 . In order for students to be able to provide responds to the items of the instrument, they ought to be acquainted with courses offered and faculty members working in their departments. For that reason, students registered to the 3rd and 4th grades were recruited based on volunteering principle. Due to missing values in the data, 39 responds were excluded and the sample size decreases to 430 participants. Table 1 below shows distribution of 430 students participated in the adaptation process of the instrument according to their faculty type and department.

Table 1. Distribution of Participants According to Faculty and Department

\begin{tabular}{llcccc}
\hline Faculty & Department & $\mathbf{N}$ & \% & Total (N) & Total (\%) \\
\hline Faculty of Economics & Business Administration & 37 & 8.6 & 109 & 25.3 \\
and Administrative & Economics & 72 & 16.7 & & \\
Sciences & & 16 & 3.7 & 96 & 22.3 \\
\hline Faculty of Engineering & Electrical and Electronics Engineering & 22 & 5.1 & & \\
and Architecture & Architecture & 26 & 6.1 & & \\
& Industrial Engineering & 32 & 7.4 & & \\
& Geology Engineering & 31 & 7.2 & 103 & \\
\hline Faculty of Arts and & Geography & 32 & 7.4 & & \\
Sciences & History & 40 & 9.3 & & \\
& Turkish Language and Literature & 40 & 9.3 & 122 & \\
\hline Faculty of Education & Computer Education and Instructional & 41.3 & & \\
& Technology & 41 & 9.5 & & \\
& Chemistry Education & 41 & 9.5 & & $\mathbf{4 0 0}$ \\
\hline
\end{tabular}

\section{Data Collection Tools}

The tool used in this study was instrument for assessing college students' perceptions of faculty knowledge in technology-supported class environments. This five-point Likert-type instrument including 50 items is developed by Shih \& Chuang (2013). Instrument items were rated as: "Never"=1, "Seldom"=2, "Sometimes"=3, "Often"=4 and "Always" $=5$. The instrument does not include any item that has a negative meaning. The instrument has 4 constructs with 9 items for subject-matter knowledge (1-9th items), 11 items for technological knowledge (1020th items), 6 items for knowledge of students' understanding/learning (21-26th items) and 24 items for technological pedagogical content knowledge (27-50th items). 
The construct - subject matter knowledge (SMK) refers to students' perception of the extent to which the teacher's competency and knowledge in learning objectives, content knowledge, and different perspectives in relation with subject-matter domain. Technological knowledge (TK) refers to students' perception of the extent to which the teacher's knowledge in digital technologies such as the Internet, digital video, interactive smart boards, and software applications. Knowledge of students' understanding (KSU) refers to students' perception of the extent to which the teacher's ability to comprehend students' prior knowledge and assess their learning during the teaching process as well as at the end of lesson units. Technological pedagogical content knowledge (TPACK) refers to students' perceptions of the extent to which the teacher possesses the knowledge with respect to technological pedagogical content knowledge as described above in 5 criteria by Angeli and Valanides (2009).

The instrument was developed through several stages. Shih and Chuang (2013), firstly, conducted a literature review about pedagogical content knowledge, technological pedagogical content knowledge, and perception of students about their teacher's knowledge. Based on the review, the authors suggested 4 constructs each of which includes adapted items. For the content validity, the expert opinions were collected; and item analysis, reliability and validity studies were also conducted.

Confirmatory factor analysis was used for construct validity. The goodness-of-fit indices RMSEA (Root Mean Square Error of Approximation) and SRMR (Standardised Root Mean Square Residual) were found to be 0.089 and 0.083 . After the examination of construct validity, item analysis and reliability analysis were conducted by using Multidimensional Version of the Rating Scale Model based on Item Response Theory (IRT). As a result of analyses, it was confirmed that students' perception of the teacher's knowledge in technology-supported class environments has multiple constructs or dimensions.

For reliability and validity processes, the instrument was administered to 383 students studying in six different faculties (engineering, liberal arts, social sciences, marine sciences, science, and management) of a national university from Taiwan. In terms of reliability analysis, based on Item Response Theory, person separation reliability technique, which is differently defined from Cronbach's alpha in the literature (Wright \& Stone, 1999), was calculated. For the four constructs of the instrument (i.e., SMK, TK, KSU, TPACK), the person separation reliabilities were calculated as $0.95,0.90,0.90$ and 0.95 . Person separation reliability value that equals to or higher than $0.7-0.8$ refers to the instrument is reliable at an acceptable degree; and that equals to or higher than the value of 0.90 refers to the instrument is reliable at a high degree (George \& Mallery, 2003).

According to reliability analysis, item 17 was found to be inconsistent with the construct; hence it was removed (Item 17: "My teacher uses PowerPoint or other similar programs to present the subject matter in class"). However, this study examined the item 17 and considered that it may behave differently in a Turkish learning context since PowerPoint is a widely-preferred application and relatively easy to use. Therefore, with the permission obtained from the authors of the original instrument, item 17 was included in the adaptation process in this study.

The reason of the adaptation of this instrument is because of it containing not only conventional technologies but also (considering the date it was developed) innovative technologies and applications (e.g., online forum, blog, podcast, virtual museum, video conferencing, Facebook, etc.); and more importantly is due to the structure including technological pedagogical content knowledge (TPACK) from a perspective of teacher competencies. Furthermore, the instrument was considered as an important one due to the fact that it is innovative and differentiated from many others in the literature in terms of its primary focus on students' perceptions of the teacher's knowledge instead of teachers' own perception of their knowledge.

\section{Cultural-Language Adaptation}

Adaptation of the instrument into Turkish was decided from three angles: (i) the original instrument emphasizes the technology usage in learning environments along with TPACK model, (ii) technologies mentioned in instrument items are being utilized in Turkish universities, and (iii) the properties to be measured in the instrument do exist and have same meanings in Turkey. The authors contacted with Dr. Ching-Lin Shih and Dr. Hsueh-Hua Chuang via email and obtained permissions to use the original instrument for adaptation into Turkish.

The translation of the original instrument from English to Turkish was done by two experts who mastered in both Turkish and English languages. After having completed the translation, Turkish draft was back translated in English. It was found that there was an equivalency of words and statements in Turkish translation with the ones 
in the original instrument. The translated version of the instrument was also examined by two experts (one from the field of instructional technology and the other from the field of measurement and evaluation) and some modifications were made accordingly. Later, the translated version was also modified in terms of Turkish grammar by an expert in Turkish language. Later, the translated instrument was administered to 25 senior students in chemistry education for cultural adaptation. Based on feedbacks collected from students, additional modifications were made and final Turkish version of the instrument consisting of 50 items with four constructs (i.e., SubjectMatter Knowledge-SMK, Technological Knowledge-TK, Knowledge of Students' Understanding-KSU, and Technological Pedagogical Content Knowledge-TPACK) was created (see Appendix).

\section{Data Collection}

In order to conduct reliability and validity studies, the Turkish version of the instrument was administered in one hour of class time to students from different faculties of a state university. Students spent about half an hour to fill in the instrument. All data were collected in two weeks.

\section{Data Analysis}

For the adaptation of an instrument, psychometric properties such as construct validity and reliability ought to be measured (Kaya, Kaya \& Emre, 2013). To test the construct validity, exploratory factor analysis (EFA) (Y1lmaz, Gürçay \& Ekici, 2007; Yılmaz, Köseoğlu, Gerçek \& Soran, 2004) or confirmatory factor analysis (CFA) (Akın, Uysal \& Çitemel, 2013; Karadeniz, Büyüköztürk, Akgün, Çakmak \& Demirel, 2008; Maindal, Sokolowski \& Vedsted, 2010) or both of them together (EFA and CFA) (Gülbahar \& Büyüköztürk, 2008; Kaya \& Dağ, 2013; Kaya et al, 2013; Öztürk \& Horzum, 2011) could be conducted. In this study, confirmatory factor analysis was used to investigate the compliance and conformity of the 4-factors of the original instrument for a different cultureTurkish sampling. CFA aims to test the compliance of the adapted instrument by comparing factors, and thus providing similarities and differences between the original and adapted instruments (Tabachnick \& Fidell, 2001).

In order to determine whether the collected data are appropriate for factor analysis, the study conducted KaiserMeyer-Olkin (KMO) Test and Bartlett's Test of Sphericity. In the process of CFA, goodness-of-fit indices - $\chi 2 /$ sd (Chi-Square/Degrees of Freedom), RMSEA (Root Mean Square Error of Approximation), NFI (Normed Fit Index), NNFI (Non-Normed Fit Index), CFI (Comparative Fit Index) and RMR (Root Mean Square Residual) were used for model-data fitness.

In addition, internal consistency reliability analysis was conducted for the reliability of the Turkish adaptation of the instrument. Cronbach's alpha was calculated to test internal consistency of items and each subscale. Furthermore, the study calculated Spearman Brown reliability coefficient and Guttmann split-half reliability coefficient. The study employed such computer software as LISREL 8.71 for CFA and SPSS Statistics 20 for KMO, Bartlett, and internal consistency tests (i.e., Cronbach's alpha, Spearman Brown, and Guttmann).

\section{Findings}

\section{Confirmatory Factor Analysis}

In confirmatory factor analysis, KMO test is used to determine whether the sample size is acceptable (Comrey \& Lee, 1992; Şencan, 2005; Tavşancıl, 2010), and Bartlett's Test of Sphericity is used whether there is normal distribution of multiple variables within data (Tabachnick \& Fidell, 2001). This study calculated Kaiser-MeyerOlkin (KMO) test as 0.922, which is considered to be a high value for factor analysis (Şencan, 2005; Tavşancil, 2010). Comrey and Lee (1992) state that a value of 0.90 or higher obtained from KMO test can be interpreted as a perfect value for sample size in order to conduct factor analysis. Moreover, the findings show that there is a normal distribution with multiple variables based on Bartlett's Test of Sphericity $\left(\chi^{2}=9184.780, p<0.01\right.$; Table 2 ), which also indicates that factor analysis can be conducted (Tabachnick \& Fidell, 2001). 
Table 2. Findings for KMO and Bartlett Tests

\begin{tabular}{lll}
\hline Kaiser-Meyer-Olkin Sample Size Test & & .922 \\
& $\chi^{2}$ & 9184.780 \\
Bartlett's Test of Sphericity & sd & 1176 \\
& $\mathrm{p}$ & .000 \\
\hline
\end{tabular}

Table 3 below shows the findings of goodness-of-fit indices based on confirmatory factor analysis. In the literature, goodness-of-fit indices - the value for $\chi^{2} /$ sd that equals to or below 5.00 (Sümer, 2000); for RMSEA that is close to 0.08 (Hooper, Coughlan \& Mullen, 2008; Jöreskog \& Sörbom, 1993; Sümer, 2000); the values for NFI, NNFI and CFI that are above 0.90 (Kelloway, 1998; Schumacker \& Lomax, 2004; Sümer, 2000; Tabachnick \& Fidell, 2001); and for RMR that is smaller than 0.80 (Brown, 2006; Hu \& Bentler, 1995, 1999) indicate a good and acceptable fit.

Table 3. Goodness-of-Fit Indices

\begin{tabular}{llllll}
\hline$\chi^{2} / \mathbf{s d}$ & RMSEA & NFI & NNFI & CFI & RMR \\
\hline 3.94 & 0.083 & 0.91 & 0.93 & 0.94 & 0.074 \\
\hline
\end{tabular}

As a result, based on confirmatory factor analysis done for construct validity, goodness-of-fit indices within this study $\left(\chi^{2} / \mathrm{sd}=3.94, \mathrm{RMSEA}=0.083, \mathrm{NFI}=0.91, \mathrm{NNFI}=0.93, \mathrm{CFI}=0.94, \mathrm{RMR}=0.074\right)$ indicate a good fit for the four-factor instrument. Besides, model fit of the instrument consisting of 4 constructs and 50 items was also tested. T-values between factors and items were calculated for model fit (see Fig. 2). The results of CFA reveal that $t-$ values changing between 5.99 and 18.62, which are higher than 2.76, are statistically significant at the .01 level. Figure 2 including no red arrows related to t-values also indicates that all items are significant at the .05 level (Jöreskog \& Sörbom, 1993). In other words, t-values show a significant relation between subscales and items in those subscales.

In summary, confirmatory factor analysis indicates that the model belongs to the original instrument was confirmed and valid to be used with its purpose in class environments in Turkey. On the other hand, the results of CFA reveal some relations between observed variables, error terms, and latent variables. Declines in the value of $\chi^{2}$ (see Table IV) does not provide considerable changes in improving the model fit nor provide meaningful suggestions based on theoretical framework. On the contrary, the analysis suggests paths for a better model fit between items 28 and 29; items 40 and 41; items 30 and 31; item 7 and the factor - technological knowledge. 


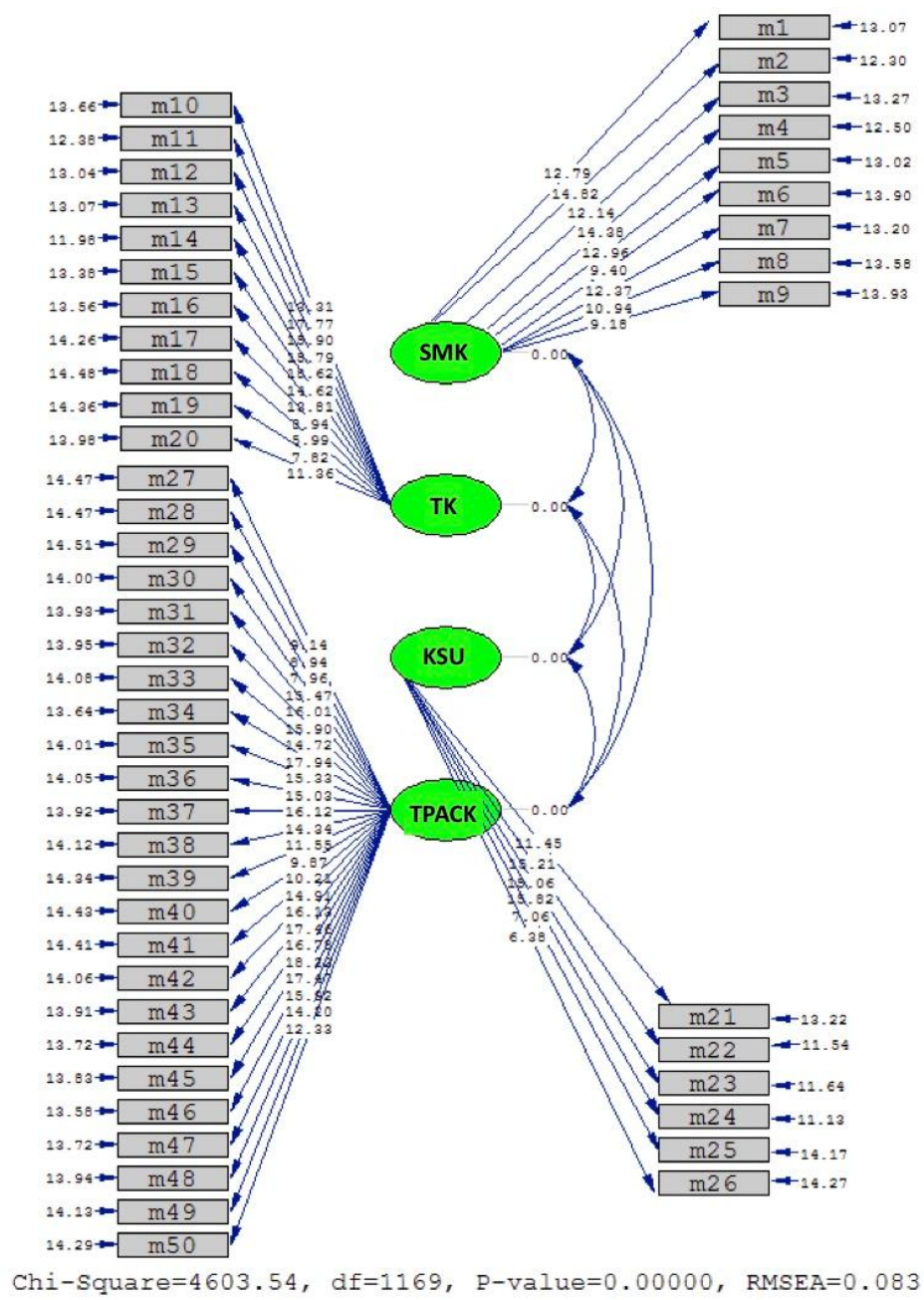

Figure 2. Confirmatory Factor Analysis Diagram (t-values)

Table 4. Suggestions for Modifications

\begin{tabular}{lll}
\hline Variables & $\begin{array}{l}\text { Decline } \\
\text { s in } \chi^{2}\end{array}$ & Items \\
\hline $\begin{array}{l}\text { Item } 28 \text { and } \\
\text { Item 29 }\end{array}$ & 200.6 & $\begin{array}{l}\text { 28. My teacher uses online discussion forums to examine the problems that may } \\
\text { occur in my learning of the subject. } \\
\text { 29. My teacher uses online discussion forums to answer my questions. }\end{array}$ \\
\hline $\begin{array}{ll}\text { Item } 40 \text { and } \\
\text { Item } 41\end{array}$ & 185.6 & $\begin{array}{l}\text { 40. My teacher uses information and communication technologies (ICTs) that } \\
\text { allow me to communicate and interact with peers from a distance. } \\
\text { 41. My teacher uses information and communication technologies (ICTs) that } \\
\text { allow me to communicate and interact with teachers or experts from a distance. }\end{array}$ \\
\hline $\begin{array}{l}\text { Item 30 and } \\
\text { Item 31 }\end{array}$ & 127.1 & $\begin{array}{l}\text { 30. My teacher uses visual aids to teach specific abstract concepts. } \\
\text { 31. My teacher uses video clips (e.g., from YouTube) to teach specific abstract } \\
\text { concepts. }\end{array}$ \\
\hline $\begin{array}{l}\text { Item 7 and } \\
\text { Technological } \\
\text { Knowledge }\end{array}$ & 97.1 & $\begin{array}{l}\text { 7. My teacher knows the relationships between the subject matter and } \\
\text { technology. }\end{array}$ \\
\hline
\end{tabular}




\section{Findings Related to Reliability}

Based on internal consistency analysis, Cronbach's alpha reliability coefficient is found to be 0.945 . For each construct of the instrument, Cronbach's alpha reliability coefficients are: 0.81 for Subject-Matter Knowledge (SMK); 0.85 for Technological Knowledge (TK); 0.73 for Knowledge of Students' Understanding (KSU); and 0.94 for Technological Pedagogical Content Knowledge (TPACK). In addition, for the entire instrument, Spearman Brown reliability coefficient was found to be 0.742 and Guttmann split-half reliability coefficient was calculated as 0.725. These results denote that internal consistency of Turkish adaptation of the instrument is high. The values of Spearman Brown reliability coefficient and Guttmann split-half reliability coefficient are relatively lower than the value of Cronbach's alpha coefficient, which could be due to items in the second half of the instrument (i.e., 26-50th items), almost all of which, fall into the last subscale (i.e., technological pedagogical content knowledge).

\section{Discussions and Conclusion}

This study adapted an instrument for "assessing undergraduate students' perceptions of faculty knowledge in technology-supported class environments" developed by Shih and Chuang (2013) into Turkish. Psychometric properties of the instrument (i.e., construct validity and reliability) were calculated by administering the instrument to 430 undergraduate students. The results of KMO and Bartlett tests were found to be appropriate to conduct construct validity and reliability analyses for an adaptation of the instrument. As a result of confirmatory factor analysis, goodness-of-fit indices revealed a good fit for 4 constructs of the instrument (SMK, TK, KSU, TPACK). In other words, the instrument along with its 4 factors was validated in Turkish sampling. Besides, t-values (obtained from CFA) revealed that factors and items belonging to each factor are significantly related. The study also reported that internal consistency analyses of an adapted instrument are prominently similar to the one in the original instrument. The results of CFA and internal consistency analyses point out that the adapted instrument is found to be valid and reliable with its original objectives in learning environments in Turkey. This study claims that adapted instrument is working similar to the original one.

It is possible to evaluate the quality of instruction via students' opinions with regards to teaching approach and their learning gains (Knight \& Waxman, 1991; Tuan et al., 2000). Therefore, instruments assessing the teacher's knowledge and the quality of instruction through students' perspectives are of great importance. In terms of widespread use of technology in learning environments, there is a need for effective assessment and measurement tools that determine the quality of technology-supported instruction and teacher's technological pedagogical content knowledge by the means of students' perceptions. Within this matter, this study presents a validated and reliable adapted instrument in Turkish for assessing students' perceptions of teacher's knowledge in technologysupported learning environments. Such valid and relevant instrument applicable to learning contexts in Turkey is considered to be crucial. It may have a contribution to training activities by Ministry of National Education (MEB, 2013) including TPACK in teacher competencies in different subject-matter domains; research projects that provide opportunities for teachers to obtain technological pedagogical content knowledge (Canbazoğlu Bilici, 2013); and studies about the degree to which teachers possess TPACK in learning environments (Allan et al., 2010; Canbazoğlu Bilici, 2012; Lee \& Tsai, 2010; Polly, 2011). Furthermore, the adapted instrument focusing on the theory of TPACK has an innovative and contributing structure since it includes new technologies (online forums, blogs, podcasts, virtual museums, video conferences, Facebook, and others).

This study introduces an adaptation of an instrument, which could be employed by educators, researchers, and scholars to examine students' perceptions of teacher's knowledge in technology-supported learning environments. By using this instrument, it is expected that researchers would have knowledge and opinions about the quality of instruction. This may produce new ideas and teaching strategies, which could increase the quality of instruction through innovative educational solutions. Moreover, some studies will be performed to investigate the adaptation of the instrument for secondary education students. However, before the instrument is administered, providing explanations and/or clarifications would be helpful in order for students to understand some specific terms or concepts rooted in the notions of technology and pedagogy. 
In today's educational system, new instructional methods and strategies based on TPACK model could give rise to new educational programs and curriculum for an effective instruction at a high degree of quality. To contribute to the field, this study conducted an adaptation of an instrument for "Assessing Undergraduate Students' Perceptions of Faculty Knowledge in Technology-Supported Class Environments” by Shih and Chuang (2013), which could be used in Turkish sampling as a valid and reliable instrument. This study is limited to the sampling of undergraduate students at a public university. Further studies could use different sample groups to provide additional validity and reliability processes of the instrument. 


\section{Öğretim Elemanlarının Teknoloji Destekli Sınıflardaki Yeterliklerine İlişkin Öğrenci Algıları Ölçeğinin Türkçeye Uyarlanması}

Giriş

Teknoloji, hızlı gelişimi ve birçok alanda (eğitim, güvenlik, sağlık, tarım, ulaşım, vs.) yaygınlaşan kullanımı ile günlük yaşamımızı şekillendiren bir hal almıştır. Teknolojinin, eğitim alanına girmesiyle, öğretim ve teknolojiyi bütünleştiren eğitim ortamları oluşmuştur (Arkorful \& Abaidoo, 2014; Preston ve diğerleri, 2015; Rabah, 2015). Teknoloji destekli öğretme ve öğrenme kaynakları ve yöntemleri, yükseköğretimde kaliteli bir eğitim sağlamak için yaygın olarak kullanılmaktadır (Bennett, Bishop, Dalgarno, Waycott \& Kennedy, 2012; Çakır, 2013; Manca \& Ranieri, 2016 Merchant, Goetz, Cifuentes, Keeney-Kennicutt \& Davis, 2014). Özellikle, teknoloji destekli öğrenme ortamları ve yeni yazılım ve donanım sistemlerinin, tekno-sosyal yaşamın yol açttğı çeşitli problemlere çözüm yaratabileceği düşünülmektedir (Hew, 2016; Hsu, Hwang, Chuang \& Chang, 2012; Tüzün \& Özdinç, 2016; Yu \& Wu, 2016). Bu noktada önemli olan öğrenme ortamında hangi teknolojinin kullanıldığı değil, teknolojinin söz konusu ortamlara nasıl entegre edildiğidir (Aksoy, 2003; Campbell \& AbdHamid, 2013; Pekdağ, 2010). Araştırmalar, bir teknolojinin öğrenme ortamına entegre edilebilmesi için yalnızca pedagojik bilgi ve alan bilgisinin yetersiz olduğunu göstermektedir. Bu noktada, alan yazında teknoloji bilgisi, teknoloji entegrasyonu için başka bir yetkinlik olarak yaygın olarak önerilmektedir. Teknoloji entegrasyonu öğretmenlerin mesleki gelişimi için zorunluluk olarak düşünülen teknoloji, pedagoji ve alan bilgisinin birlikte kullanılmasını gerektirmektedir (Angeli \& Valanides, 2009; Campbell \& Abd-Hamid, 2013; Koehler, Mishra \& Yahya, 2007, 2007; Mishra \& Koehler, 2006; Pamuk, 2012; Pekdağ, 2015). Sonuç olarak, teknolojik pedagojik alan bilgisinin (TPAB) yeni ve önemli bir yetkinlik olarak ortaya çıktığı çok sayıda araştırma raporunda belirtilmektedir (Allan, Erickson, Brookhouse \& Johnson 2010; Chen \& Jang, 2014; Graham ve diğerleri, 2009; Hao, 2016; Lee \& Tsai, 2010; Öztürk, 2013; Polly, 2011).

Bu yeni bilgi türü (TPAB), 2013 yılında Türkiye'de "Ulusal Öğretmen Strateji Belgesi Taslağı"nda öğretmenler için kritik bir yetkinlik olarak belirtilmiştir. Taslak raporun "Hizmet Öncesi Öğretmen Yetiştirme Geliştirme" başlığında, pedagojik formasyon kavramı yerine disiplinler arası ve bütünsel öğretim programlarını içeren TPAB kavramına vurgu yapılmıştır (MEB, 2013). Türk Eğitim Derneği tarafından hazırlanan "Öğretmen Yeterlikleri" raporunda; Teknolojik Pedagojik Alan Bilgisi (TPAB) öğretmen yeterlikleri içerisinde sıralanmakta ve "öğretim programları ve konu alanı, programın nasıl öğretileceği, alanın diğer alanlarla ilișkisi, alandaki son gelişmeler, alanın temel kavram, araç ve yapıları ve öğretilecek içeriğin teknoloji ile bütünleştirilmesi hakkında bilgili olma" şeklinde tanımlanmaktadır (TED, 2009, s.7). Ayrıca, Türkiye Bilimsel ve Teknolojik Araştırma Kurumu (TÜBİTAK)'nun öğretmenlere teknolojik pedagojik alan bilgisi kazandırma amaçlı eğitim uygulamaları ile ilgili projelere destek verdiği görülmektedir (Canbazoğlu Bilici, 2013). Sonuç olarak teknolojik, pedagojik alan bilgisinin öğretmenlerin mesleki gelişiminde temel unsurlar olarak kabul edildiği ifade edilebilir.

\section{Teknolojik Pedagojik Alan Bilgisi (TPAB)}

Shulman (1987) öğretmenlerin mesleki bilgilerinin, pedagojik bilgi ve alan bilgisinden ve dolayısıyla pedagojik alan bilgisinden oluştuğunu ifade etmektedir. Alan yazın (Angeli \& Valanides, 2005; Mishra \& Koehler, 2006; Niess, 2005), Shulman'ın (1987) pedagojik alan bilgisinin (PAB), teknoloji ile eğitimi de içine alacak biçimde genişletilmesine ihtiyaç olduğu yönünde birleşmektedir. Mishra ve Koehler (2006), PAB'a ek olarak teknolojik bilgiyi önererek, teknolojik pedagojik alan bilgisini kavramını oluşturmuştur. TPAB, öğretmenler için gerekli olan farklı bilgi türlerinin karşılıklı etkileşimine odaklanan yeni bir teorik çerçeve (bkz. Şekil 1) sunmaktadır (Koehler ve diğerleri, 2007). Bu çerçevedeki bilgi kategorileri aşağıdaki gibi tanımlanmaktadır:

1. Teknolojik Bilgi (TB), "geleneksel, güncel ve gelişmekte olan çeşitli teknolojilere ilişkin bilgi ve beceriler" (Chen \& Jang, 2014, p.81) or "teknoloji okuryazarlı̆̆ı, günlük hayatta teknoloji kullanımı ve teknolojik değişime uyum sağlamaya ilişkin bilgi”'(Öztürk \& Horzum, 2011, p.257);

2. Alan Bilgisi (AB), "öğrenilecek veya öğretilecek alan ile ilgili sahip olunan bilgi” (Mishra \& Koehler, 2006, p.1026);

3. Pedagojik Bilgi $(P B)$, "sınıf yönetimi, değerlendirme, ders planı geliştirme gibi öğretim yöntem ve süreçlerine ilişkin bilgi”" (Schmidt ve diğerleri, 2009, p.125);

4. Pedagojik Alan Bilgisi (PAB), "Daha iyi öğretim yapabilmek için içeriğin ve pedagojinin harmanlanmasına ilişkin bilgi" (Chen \& Jang, 2014, p.81);

5. Teknolojik Alan Bilgisi (TAB), "medya seçimi veya içeriği dönüştürmek/sunmak için teknolojik araçların kullanımına ilişkin bilgi" (Chen \& Jang, 2014, p.81) veya "belirli bir içerik için teknolojinin nasıl yeni sunumlar oluşturabileceğine ilişkin bilgi " (Schmidt ve diğerleri, 2009, p.125); 
6. Teknolojik Pedagojik Bilgi (TPB), "teknolojinin sağladığı firsatların farkında olma ve öğretme stratejileri ile bu olanakların nasıl birleştirilebileceğine ilişkin bilgi" (Chen \& Jang, 2014, p.81) veya "çeşitli teknolojilerin öğretimde nasıl kullanılabileceği bilgisi”" (Schmidt ve diğerleri, 2009, p.125);

7. Teknolojik Pedagojik Alan Bilgisi (TPAB), “öğretmenlerin alan, pedagoji ve teknoloji arasındaki etkileşimi anlamalarının yanı sıra, teknolojileri öğretim alışkanlıklarına entegre etme bilgisi” (Chen \& Jang, 2014, p.81) veya "Öğretmenlerin herhangi bir içeriğin öğretim sürecine teknolojiyi entegre etmeleri için gerekli bilgi” (Schmidt ve diğerleri, 2009, p.125).

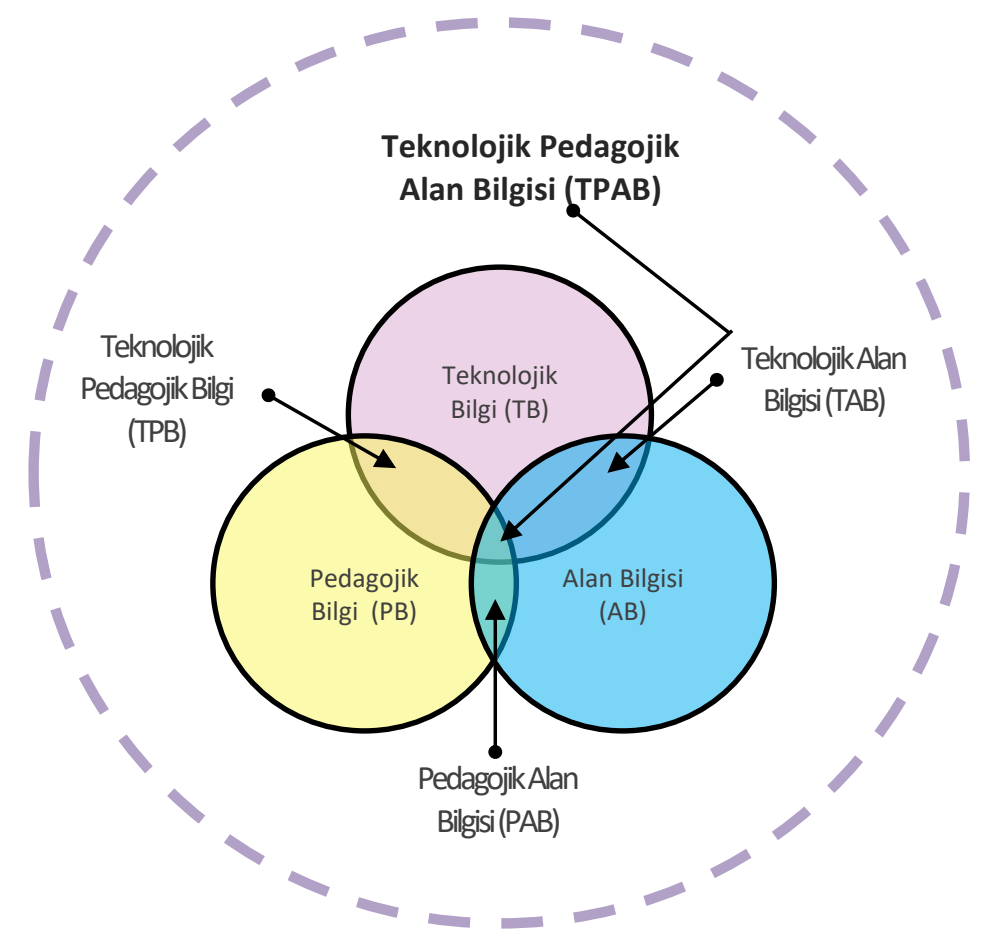

Şekil 1. TPAB Çerçevesi (Koehler ve Mishra, 2012)

Bir konunun öğretiminde teknolojinin etkin olarak kullanılabilmesi; yalnızca alan, teknoloji ve pedagoji bilgisi değil, aynı zamanda bu bilgi türlerinin birbirleriyle olan ilişkilerini de gerektirir. Koehler ve diğerleri (2007) TPAB'ın odağında alan, pedagoji ve teknoloji arasında dinamik ve işlemsel ilişki olduğunu belirtmişlerdir. Teknoloji ile iyi bir öğretim sağlamak için, ilgili konuya özgü, uygun strateji ve sunumla birlikte üç unsurun birbirilerini güçlendirici ilişkilerini anlamak gerekir (s.741).

TPAB, öğretmenlerin bilgisini arttırmak, teknoloji entegrasyonu hakkındaki bilgilerine ilişkin verileri toplamak ve düzenlemek için bir çerçeve olarak sunulmaktadır. Angeli ve Valanides (2009, s. 163-164) teknolojik pedagojik alan bilgisini belirlemek amacıyla aşağıda ifade edilen beş kriteri tanımlamışlardır:

1. Teknoloji yardımı ile öğretilecek konuların belirlenmesi (öğrencilerin kolayca anlaması mümkün olmayan konuların veya öğretmenlerin etkili öğretimde zorlandıkları konuların belirlenmesi).

2. İçeriğin öğrencilerin kolayca anlayabileceği biçime dönüştürülmesi için uygun gösterimlerin belirlenmesi.

3. Geleneksel yollarla uygulaması zor veya imkansız olan öğretim stratejilerinin belirlenmesi

4. Uygun teknolojik araçların seçilmesi ve bu araçların pedagojik olarak nasıl etkili kullanılacağının belirlenmesi

5. Teknolojinin öğretim ortamına entegre edilmesi için uygun stratejilerin belirlenmesi (görüşünü ifade etmek, gözlemlemek, araştırmak, sorgulamak ve genel olarak problem çözmek için öğrenciyi öğrenme sürecinin merkezine koyan bir stratejinin belirlenmesi). 
TPAB çerçevesi öğretmenlerin bilgi kategorilerini incelemek için analitik bir bakış veya araç sağlamaktadır (Chen \& Jang, 2014, s.79). TPAB, birçok alanda başarılı öğrenci öğrenimi için çok önemli olan öğretmen bilgilerinin değerlendirilmesine odaklanmaktadır (Schmidt ve diğerleri, 2009).

\section{Araştırmanın Amacı}

Alanyazında Mishra ve Koehler (2006) tarafından önerilen TPAB modeli çerçevesinde geliştirilmiş ve yaygın olarak kullanılan belirli anket ve ölçekler olduğu görülmektedir. Schmidt ve diğerleri (2009) öğretmenlerin TPAB gelişimlerini belirlemek amacıyla bir ölçek geliştirmişlerdir. Ölçekte öğretmen adaylarının yedi bilgi alanındaki bilgilerini TPAB çerçevesindeki ölçmek için 8 TB, 17 AB, 10 PB, 8 PAB, 8 TAB, 15 TPB ve 9 TPAB olmak üzere, öz değerlendirme yapmaları istenen 75 madde yer almaktadır. Bu ölçeğin Türkçe uyarlaması Öztürk ve Horzum (2011), Kaya ve Dağ (2013) ve Kaya, Kaya ve Emre (2013) tarafindan yapılmıştır.

Graham ve diğerleri (2009) ise dört TPAB boyutuna odaklanarak, fen bilgisi öğretmenlerinin TPAB konusundaki özgüvenlerini belirleyen bir ölçek geliştirmişlerdir. Bu ölçek, Timur ve Taşar (2011) tarafindan Türkçe'ye uyarlanmıştır. Diğer taraftan, Archambault ve Crippen (2009) de, uzaktan eğitim veren K-12 öğretmenlerinin TPAB boyutlarındaki bilgilerini belirlemek üzere 24 maddelik bir anket kullanmışlardır. Başka bir ölçme aracı ise, Lee ve Tsai (2010)'in geliştirdiği, World Wide Web'in eğitimsel kullanımı ile ilgili Tayvan'lı öğretmenlerin öz yeterlik ve TPAB düzeylerini belirlemeyi amaçlayan bir ölçektir.

Öğretmen adaylarının veya öğretmenlerin teknoloji ile öğretim hakkındaki kendi bilgilerine ilişkin algılarını belirlemek amacıyla TPAB modeli ile ilgili çok sayıda ölçek ve anketler geliştirilmiştir. Bu çalışmalarda, TPAB düzeyleri öğretmen adaylarının veya öğretmenlerin kendilerine sorulmuştur (Akgün, 2013; Kaya \& Dağ, 2013; Kaya ve diğerleri; Öztürk, 2013; Öztürk \& Horzum, 2011). Buna karşılık, öğrencileri okul yaşantısının temel bileşeni olarak görüp, onların teknoloji destekli sınıflarda öğretmeninin öğretimini nasıl algıladığı üzerine odaklanan araştırmalar sinırlıdır (Lee, 2011; Shih \& Chuang, 2013).

Öğrenme ortamı çalışmaları; öğrencilerin algılamalarına ve öğrenme görevlerine nasıl cevap verdiklerine vurgu yapan öğrenci biliş paradigmasına (student cognition paradigm) dayanmaktadır. Bu paradigmaya göre, sınıf öğretiminin öğrenciler tarafından algılanan kalitesi, öğretimin gözlenen kalitesinden daha önemlidir (Knight \& Waxman, 1991). Bazı araştırmalar öğretmen bilgisi hakkında özellikle öğrencilerin algılarının araştırılmasının önemine vurgu yapmaktadırlar. Bu araştırmalarda; öğretme etkinliğinin, öğrencilerin öğretme işini nasıl gördüklerinin incelenmesi ile geliştirilebileceği ifade edilmiştir (Knight \& Waxman 1991; Tuan, Chang, Wang \& Treagust, 2000). Bu doğrultuda, öğretmenlerin teknolojiyi kullanarak öğretim yapabilme yetkinliklerinin öğrenciler tarafından nasıl algılandığı büyük öneme sahiptir.

Türkiye'de, öğretim elemanlarının teknoloji destekli sınıflardaki bilgi düzeylerini öğrenci algılarıyla belirleyen bir ölçeğe rastlanmamıştır. Bu amaçla geliştirilmiş, geçerlik ve güvenirlik çalışmaları yapılarak sunulmuş bir ölçeğin Türkçeye uyarlanması bu alanda yapılacak araştırmalara katkı sağlayacaktır. Belli bir kültür için hazırlanmış olan bir psikolojik ölçme aracı farklı kültür ve dillere çevrilerek de kullanılabilmektedir. Bir ölçeğin yalnızca başka bir dile çevrilerek kullanılması yerine, o ölçekle ilgili temel psikometrik işlemlerin de yapılması ölçeğin başka dil ve kültürlere uyarlanması olarak bilinmektedir (Deniz, 2007). Bu bağlamda bu çalışma, Shih ve Chuang (2013) tarafından geliştirilen "Öğretim Elemanlarının Teknoloji Destekli Sınıflardaki Bilgilerine İlişsin Öğrenci Algıları Ölçeği”nin Türkçeye uyarlamasını amaçlamaktadır.

\section{Yöntem}

\section{Çalışma Grubu}

Araştırma, 2012-2013 eğitim-öğretim yılında bir devlet üniversitesinin faklı fakültelerine kayıtlı 469 öğrenci ile yürütülmüştür. Araştırmaya katılan öğrencilerin yaş ortalaması 21'dir. Katılımcıların, uygulanacak ölçek maddelerine yeterli düzeyde cevap verebilmeleri için, bölümlerinde öğretimi yapılan dersler ve görev yapan öğretim elemanlarının öğretimleri hakkında bilgi sahibi olmaları gerekmektedir. Bu amaçla, katılımcıların lisans programlarının 3. ve 4. sınıflarında okumaları esas alınmıştır. Ayrıca, araştırmaya katılımda gönüllülük esası 
aranmıştır. Veri setindeki kayıp veriler ve uç değerlerin çıkarılması sonucunda 430 kişilik bir veri elde edilmiştir. Ölçek uyarlama çalışmasına katılan 430 öğrencinin fakülte ve bölümlere göre dağılımı Tablo 1'de sunulmaktadır.

Tablo 1. Çalışma Grubunun Fakülte ve Bölümlere Göre Dağılımı

\begin{tabular}{|c|c|c|c|c|c|}
\hline Fakülte & Bölüm & $\mathbf{N}$ & $\%$ & Toplam (N) & Toplam (\%) \\
\hline İktisadi ve İdari & İktisat & 37 & 8.6 & 109 & 25.3 \\
\hline Bilimler Fakültesi & İşletme & 72 & 16.7 & & \\
\hline Mühendislik & Elektrik-Elektronik Mühendisliği & 16 & 3.7 & 96 & 22.3 \\
\hline Mimarlık & Mimarlık & 22 & 5.1 & & \\
\hline \multirow[t]{2}{*}{ Fakültesi } & Endüstri Mühendisliği & 26 & 6.1 & & \\
\hline & Jeoloji Mühendisliği & 32 & 7.4 & & \\
\hline Fen-Edebiyat & Coğrafya & 31 & 7.2 & 103 & 23.9 \\
\hline \multirow{2}{*}{ Fakültesi } & Tarih & 32 & 7.4 & & \\
\hline & Türk Dili ve Edebiyatı & 40 & 9.3 & & \\
\hline \multirow[t]{4}{*}{ Eğitim Fakültesi } & $\begin{array}{l}\text { Bilgisayar ve Öğretim Teknolojileri } \\
\text { Eğitimi }\end{array}$ & 40 & 9.3 & 122 & 28.3 \\
\hline & Kimya Eğitimi & 41 & 9.5 & & \\
\hline & Sınıf Öğretmenliği & 41 & 9.5 & & \\
\hline & Toplam & 430 & 100 & 430 & 100 \\
\hline
\end{tabular}

\section{Veri Toplama Aracı}

Öğretim Elemanlarının Teknoloji Destekli Sınıflardaki Bilgilerine İlişkin Öğrenci Algıları Ölçeği, Shih ve Chuang (2013) tarafından geliştirilmiş, 50 maddeli Likert tipi bir ölçektir. Ölçek maddeleri; "Hiçbir zaman"=1, "Nadiren"=2, "Bazen"=3, "Genellikle"=4 ve "Her zaman"=5 olarak puanlanmıştır. Ölçekte negatif ifadeli madde bulunmamaktadır. Ölçekte; Alan Bilgisi (1-9. maddeler), Teknolojik Bilgi (10-20. maddeler), Öğrenmeye İlişkin Bilgi (21-26. maddeler) ve Teknolojik Pedagojik Alan Bilgisi (27-50. maddeler) olmak üzere 4 alt boyut bulunmaktadır. Alan Bilgisi (AB) alt boyutu; öğretim elemanının konu alanına ilişkin amaçları, bilgileri ve fikirleri bilme derecesi hakkında öğrenci algılarını ifade etmektedir. Teknolojik Bilgi (TB) alt boyutu; öğretim elemanının internet, video, interaktif yazı tahtaları ve uygulama yazılımları gibi dijital teknolojiler ile ilgili sahip olduğu bilgilerin derecesine ilişkin öğrenci algılarını ifade etmektedir. Öğrenmeye İlişkin Bilgi (ÖİB) alt boyutu; öğretim elemanının öğrencilerin ön bilgilerini bilme ve öğretim sürecinde ve konu/ünite sonunda öğrencilerin öğrenmelerini değerlendirebilme derecesine ilişkin öğrenci algılarını ifade etmektedir. Teknolojik Pedagojik Alan Bilgisi (TPAB) alt boyutu ise; öğretim elemanının Angeli ve Valanides (2009) tarafından önerilen beş kriter ile tanımlanmış teknolojik pedagojik alan bilgisine sahip olma derecesine ilişkin öğrenci algılarını ifade etmektedir.

Ölçek çeşitli aşamalardan geçerek geliştirilmiştir. Shih ve Chuang (2013) ilk olarak, pedagojik alan bilgisi, teknolojik pedagojik alan bilgisi ve öğretmen bilgisine ilişkin öğrenci algıları üzerine literatür incelemesi yapmışlardır. Bu incelemeler sonunda ölçekle ile ilgili dört alt boyut önerilmiştir. Belirlenen bu dört alt boyutun her birisi için maddeler yazılmış ve daha sonra gerekli düzeltmeler yapılmıştır. Ölçek içeriğinin geçerliğine ilişkin uzmanlara danışılmıştır. Madde analizleri ve ölçeğin geçerlik ve güvenirlik çalışmaları yapılmıştır.

Ölçeğin yapı geçerliği doğrulayıcı faktör analizi ile test edilmiş, uyum iyiliği indeksleri RMSEA (Root Mean Square Error of Approximation) ve SRMR (Standardised Root Mean Square Residual) için sirasiyla 0.089 ve 0.083 değerleri bulunmuştur. Ölçeğin yapı geçerliği kontrol edildikten sonra, Madde Tepki Kuramına dayalı çok boyutlu derecelendirme ölçeği modeli (Multidimensional Version of the Rating Scale Model) kullanılarak madde ve güvenirlik analizleri yapılmıştır. Yapılan analizler sonucunda, öğretim elemanlarının teknoloji destekli sınıflardaki yeterliklerine ilişkin öğrenci algılarının çok boyutlu bir yapısı olduğu doğrulanmıştır.

Geçerlik ve güvenirlik çalışmaları için güney Tayvan'daki ulusal bir üniversitenin 6 fakültesinde (mühendislik, beşeri bilimler, sosyal bilimler, deniz bilimleri, fen bilimleri ve yönetim) öğrenim gören toplam 383 öğrenciye ölçek uygulanmıştır. Ölçeğin güvenirliğini analiz etmek için, Madde Tepki Kuramına dayalı, gerçek yetenek varyansının örneklem varyansına oranı olan, 'ayırıcılık güvenirliği' (person separation reliability) hesaplanmıştır. 
Ayırıcılık güvenirliği, Cronbach alfadan farklı tanımlanmaktadır, fakat bu ikisi de güvenilirliğin karşılaştırılabilir ölçümleridir (Wright \& Stone, 1999). Ölçeğin dört alt boyutuna (AB, TB, ÖİB, TPAB) ilişkin ayırıcılık güvenirlikleri sırasıyla $0.95,0.90,0.90$ ve 0.95 olarak hesaplanmıştır. Ayırıcılık güvenirliğinin, $0.7-0.8$ 'e eşit ya da büyük olması ölçeğin kabul edilebilir bir güvenirliğe sahip olduğunu, 0.90 ve üzerinde olması ise ölçeğin yüksek derecede güvenilir olduğunu göstermektedir (George \& Mallery, 2003).

Ölçeğin geliştirilme aşamasında 50 madde yazılmıştır. Çok boyutlu derecelendirme ölçeği ile yapılan analizler sonucunda yapıya uyum göstermediği belirlenen 17. madde ölçekten çıkarılmıştır. kullanir.

17. madde: Öğretmenim dersin içeriğini sunmak amacıla PowerPoint'i ve benzer diğer programları

Ölçekten çıkarılan bu 17. madde incelenmiş, Türkiye'deki öğretim ortamlarında PowerPoint'in sıkça tercih edilen ve nispeten kolay bir yazılım türü olmasından ötürü Türkiye'de bu maddenin farklı davranabileceği düşünülmüştür. Bu sebeple, ölçek yazarlarından izin alınarak bu madde uyarlama sürecine dahil edilmiştir.

Ölçeğin uyarlamaya değer görülmesinin temel sebebi; ölçeğin yalnızca kısıtlı bazı teknolojileri değil, geliştirildiği tarih ve öğretimde kullanımı itibariyle yeni sayılabilecek teknolojileri ve uygulamalarını (online forum, blog, podcast, sanal müze, video konferans, facebook, vb.) ve son zamanlarda öğretmen yeterlilik alanı içerisine dahil edilen teknolojik pedagojik alan bilgisini (TPAB) de içine alan bir yapısının olmasıdır. Ayrıca, öğretmenin kendi bilgisi hakkındaki algısını değil, öğrencinin gözünden öğretmenin bilgisini irdelemesi açısından farklı, yenilikçi ve katkı getirici bulunması da önemli bir tercih sebebidir.

\section{Kültürel-Dilsel Uyarlama}

Orijinal ölçeğin, öğretim ortamlarında teknoloji kullanımını konu alması ve TPAB modelini içermesi, ölçek maddelerinde geçen teknolojilerin üniversitelerde kullanılıyor olması ve ölçülmek istenen özelliğin Türkiye'de de var olan ve aynı anlama gelen bir özellik olması dolayısıyla, ölçeğin Türkçeye uyarlanmasına karar verilmiştir. Uyarlama çalışmasına başlamadan önce Dr. Ching-Lin Shih ve Dr. Hsueh-Hua Chuang ile e-posta yoluyla irtibata geçilmiş ve özgün formun Türkçeye uyarlanmasında kullanılması için izin alınmıştır.

Orijinal ölçeğin İngilizceden Türkçeye çevirisi her iki dile hâkim İngiliz Dili alanında iki uzman tarafından yapılmıştır. Çeviri işlemi tamamlandıktan sonra, Türkçe taslak formdaki kelimelerin ve ifadelerin orijinal ölçekle eşdeğerliğinin karşılaştırılması amacıyla, taslak form iki uzman tarafından tekrar İngilizceye çevrilmiştir. Yapılan incelemede, orijinal ölçekteki maddeler ile Türkçe formdaki maddelerin dil denkliğinin olduğu görülmüştür. Çeviri; içerik ve ölçme değerlendirme açısından araştırmacılar (biri öğretim teknolojileri alanında, diğeri ise öğretim teknolojileri ve ölçme değerlendirme alanlarında uzman) tarafından incelenmiş ve tekrar düzenlenmiştir. Oluşan çeviri formu, Türkçe dilbilgisi ve gramer yapısı açısından incelenmek üzere Türk Dili uzmanının görüşüne sunulmuştur. Öneriler doğrultusunda gerekli düzeltmeler yapılmıştır. Çevirisi tamamlanan ölçek daha sonra, anlaşılabilirlik ve okunabilirlik açısından test edilmesi amacıyla Kimya Eğitimi 5. sınıfında öğrenim gören 25 kişilik bir öğrenci grubuna uygulanmıştır. Ölçeğin doldurulmasından hemen sonra ölçek maddelerinin anlaşılabilirliği hakkında öğrencilerin görüşleri alınmıştır. Öğrencilerden gelen dönütler doğrultusunda gerekli düzeltmeler yapılarak ölçeğe son hali verilmiştir.

Dil uyarlaması sonucunda orijinal ölçek; (i) ismi "öğretim elemanlarının teknoloji destekli sınıflardaki yeterliklerine ilişkin ögrrenci algıları ölçeği” olarak belirlenen, (ii) 4 alt boyutta sahip (Alan Bilgisi/AB, Teknolojik Bilgi/TB, Öğrenmeye İlişkin Bilgi/ÖİB, Teknolojik Pedagojik Alan Bilgisi/TPAB), (iii) 50 maddeden oluşan ve (iv) 5'li Likert yapıda (hiçbir zaman, nadiren, bazen, genellikle, her zaman) Türkçe olarak uygulanabilir bir ölçek haline gelmiştir (bkz. Ek).

\section{Verilerin Toplanması}

Türkçeye dil uyarlaması yapılan ölçek, geçerlik ve güvenirlik çalışmalarının yapılması amacıyla, 2012-2013 eğitim-öğretim yılının Mayıs ayı içerisinde bir devlet üniversitesinin faklı fakültelerinde öğrenim gören katılımcı öğrencilere cevaplamaları için dağıtılarak, bir ders saatinde uygulanmıştır. Ölçeğin doldurulması yaklaşık 30 dakika sürmüştür. Verilerin toplanması 2 haftalık bir zaman almıştır. 


\section{Verilerin Analizi}

Dil uyarlaması yapılan ölçeğin Türkiye'de uygulanabilirliğinin belirlenmesi amacıyla yapı geçerliği ve güvenirliği gibi psikometrik özellikleri test edilmelidir (Kaya ve diğerleri, 2013). Uyarlama çalışmalarında ölçeğin yapı geçerliğini test etmek için açımlayıcı faktör analizi (AFA) (Yılmaz, Gürçay \& Ekici, 2007; Yılmaz, Köseoğlu, Gerçek \& Soran, 2004) veya doğrulayıcı faktör analizi (DFA) (Akın, Uysal \& Çitemel, 2013; Karadeniz, Büyüköztürk, Akgün, Çakmak \& Demirel, 2008; Maindal, Sokolowski \& Vedsted, 2010) veya her iki analizde birlikte (AFA ve DFA) (Gülbahar \& Büyüköztürk, 2008; Kaya \& Dă̆, 2013; Kaya ve diğerleri, 2013; Öztürk \& Horzum, 2011) yapılabilmektedir. Bu çalışmada, orijinal ölçekteki yapının farklı bir kültürdeki uyumu incelendiğinden dolayı, ölçeğin yapı geçerliğini test etmek için doğrulayıcı faktör analizi yapılmıştır. Bir başka ifade ile orijinal ölçeğin 4 faktörlü yapısının Türkiye örnekleminde doğrulanıp doğrulanmayacağını ortaya koymak üzere DFA yapılmıştır. DFA, orijinal ölçeğin iddia ettiği modeli sınamayı ve modelin uygunluğunu test etmeyi amaçlamaktadır. DFA'da, uyarlanan ölçeğin faktör yapısı ile orijinal ölçeğin faktör yapısı karşılaştırılmakta, benzerlikler ve farklı1ıklar ortaya konulmaktadır (Tabachnick \& Fidell, 2001).

Faktör analizinin yapılabilmesi için öncelikle, araştırmaya katılan 430 üniversite öğrencisinden toplanan verinin faktör analizi yapmaya uygun olup olmadığının belirlenmesi amacıyla Kaiser-Meyer-Olkin (KMO) Testi ve Bartlett Küresellik Testi (Bartlett's Test of Sphericity) yapılmıştır. DFA sürecinde modelin uygunluğu değerlendirilirken birbirinden farklı uyum iyiliği indeksleri göz önüne alınmaktadır. Bu çalışmanın DFA sürecinde; $\chi^{2} / \mathrm{sd}$ (Chi-Square/Degrees of Freedom), RMSEA (Root Mean Square Error of Approximation), NFI (Normed Fit Index), NNFI (Non-Normed Fit Index), CFI (Comparative Fit Index) ve RMR (Root Mean Square Residual) uyum iyiliği indeksleri (goodness-of-fit indices) ölçüt alınmış, bu uyum iyiliği indekslerinin değerlerinin yeterlilik düzeyleri incelenmiştir.

Türkçeye uyarlanan ölçeğin güvenirliğini incelemek amacıyla iç tutarlılık analizleri yapıllmıştı. Ölçek maddelerinin birbirleriyle tutarlılığını test etmek amacıyla tüm ölçek ve her bir alt boyut için Cronbach alfa güvenirlik katsayısı hesaplanmıştır. Ayrıca, tüm ölçek için Spearman Brown güvenirlik katsayısı ve Guttmann iki yarı güvenirlik katsayısı hesaplanmışır. DFA için LISREL 8.71 bilgisayar yazılımı, KMO ve Bartlett testleri ve iç tutarlılık (Cronbach alfa, Spearman Brown ve Guttmann) analizleri için ise SPSS Statistics 20 bilgisayar yazılımı kullanılmıştır.

\section{Bulgular}

\section{Doğrulayıcı Faktör Analizi (DFA) Bulguları}

Faktör sayısını saptama (AFA) veya doğrulama analizinde (DFA), faktör analizi yapmak için verilerin (örneklem büyüklüğünün) yeterli olup olmadığı KMO testiyle (Comrey \& Lee, 1992; Şencan, 2005; Tavşancıl, 2010), verilerin çok değişkenli normal bir dağılım oluşturup oluşturmadığı ise Bartlett Küresellik testiyle (Tabachnick \& Fidell, 2001) belirlenmektedir.

$\mathrm{Bu}$ çalışmada, Kaiser-Meyer-Olkin (KMO) testinden elde edilen değer 0.922 olarak bulunmuştur. Bu değer, 430 ögrenciden toplanan verinin faktör analizi yapmak için yeterli olduğunu göstermektedir (Şencan, 2005; Tavşancıl, 2010). Comrey ve Lee (1992), KMO testinden elde edilen değerin 0.90 ve üstü olması durumunda, faktör analizi yapmak için örneklem büyüklüğünün mükemmel olarak yorumlanabileceğini ifade etmişlerdir. Bunun yanında Bartlett Küresellik testinin sonucunun $\left(\chi^{2}=9184.780, \mathrm{p}<0.01\right.$; Tablo 2$)$ anlamlı çıkması, verilerin çok değişkenli normal bir dağılım oluşturduğunu göstermekte ve dolayısıyla verilerin faktör analizi yapmaya uygun olduğu anlamına gelmektedir (Tabachnick \& Fidell, 2001). 
Tablo 2. KMO ve Bartlett Testlerinin Sonuçları

\begin{tabular}{lll}
\hline \multicolumn{2}{l}{ Kaiser-Meyer-Olkin Örneklem Büyüklüğ̈̈ Testi } & .922 \\
\hline \multirow{3}{*}{ Bartlett Küresellik Testi } & $\chi^{2}$ & 9184.780 \\
& $\mathrm{sd}$ & 1176 \\
& $\mathrm{p}$ & .000 \\
\hline
\end{tabular}

Doğrulayıcı faktör analizi sonucunda ulaşılan uyum iyiliği değerleri Tablo 3'te sunulmuştur. DFA'da elde edilen $\chi^{2}$ /sd uyum indeksinin 5 veya altında olması, modelin gerçek verilerle iyi uyum gösterdiği şeklinde yorumlanmaktadır (Sümer, 2000). RMSEA değerinin 0.08'e çok yakın olması (Hooper, Coughlan \& Mullen, 2008; Jöreskog \& Sörbom, 1993; Sümer, 2000); NFI, NNFI ve CFI değerlerinin 0.90'ın üzerinde olması (Kelloway, 1998; Schumacker \& Lomax, 2004; Sümer, 2000; Tabachnick \& Fidell, 2001) ve RMR değerinin de 0.80'den küçük olması (Brown, 2006; Hu \& Bentler, 1995, 1999) modelin iyi uyum gösterdiğini ortaya koymaktadır.

Tablo 3. Uyum İyiliği İndeksleri

\begin{tabular}{llllll}
\hline$\chi^{2} / \mathbf{s d}$ & RMSEA & NFI & NNFI & CFI & RMR \\
\hline 3.94 & 0.083 & 0.91 & 0.93 & 0.94 & 0.074 \\
\hline
\end{tabular}

Sonuç olarak, Türkçeye uyarlanan “öğretim elemanlarının teknoloji destekli sınıflardaki yeterliklerine ilişkin öğrenci algıları ölçeği’”nin yapı geçerliğini test etmek amacıyla yapılan doğrulayıcı faktör analizi sonucunda elde edilen uyum iyiliği değerleri $\left(\chi^{2} / \mathrm{sd}=3.94\right.$, RMSEA=0.083, NFI=0.91, NNFI=0.93, CFI=0.94, RMR=0.074), çalışma grubundan elde edilen verilerle ölçeğin Türkçe formunun yapısının (ölçekteki dört alt boyutlu yapının) iyi uyum gösterdiğini ortaya koymuştur.

Diğer taraftan, Türkçeye uyarlanan 4 faktör (4 alt boyut) ve bu faktörlerle ilişkili 50 maddeden oluşan ölçeğin model uyumu test edilmiştir. Model uyumu için faktörler ve maddeler arasındaki t değerlerine bakılmıştır (Şekil 2). DFA sonucunda, faktörler ve maddeler arasındaki t değerlerinin 5.99 ile 18.62 arasında değiştiği ve 2.76 'dan yüksek olduğu için .01 düzeyinde anlamlı çıktığı belirlenmiştir. Şekil 2'de t değerleri ile ilgili kırmızı ok bulunmaması tüm maddelerin .05 düzeyinde anlamlı olduğunu ifade etmektedir (Jöreskog \& Sörbom, 1993). Bir başka ifade ile DFA sonucunda elde edilen t değerleri, ölçeğin tüm alt boyutları ile bu alt boyutlara ait maddeler arasındaki ilişkilerin anlamlı olduğuna işaret etmektedir. Doğrulayıcı faktör analizinden elde edilen sonuçlar, orijinal ölçeğin ortaya koyduğu modelin doğrulandığını ve ölçeğin Türkiye'de amacı doğrultusunda geçerli olduğunu ifade etmektedir.

Öte yandan yapılan DFA analizi; gözlenen değişkenler, hata terimleri ve gizil değişkenler arasında bazı ilişkiler önermiştir. DFA analizi sonucunda $\chi^{2}$ değerindeki düşüşler (Tablo 4), model uyumunun iyileşmesinde dikkate değer değişimler sağlamadığını ve modelin kuramsal çerçevesinde de bu önerilerin bir anlam ifade etmediğini ortaya koymuştur. Buna karş1lık, analiz sonucunda; madde 28 ile madde 29, madde 40 ile madde 41, madde 30 ile madde 31 ve madde 7 ile Teknolojik Bilgi alt boyutu arasında nispeten uyuma daha çok katkı sağlayacak yol önerilerin bulunduğunu belirtmek benzer araştırmalarda madde yazımına katkı sağlayabilir. 


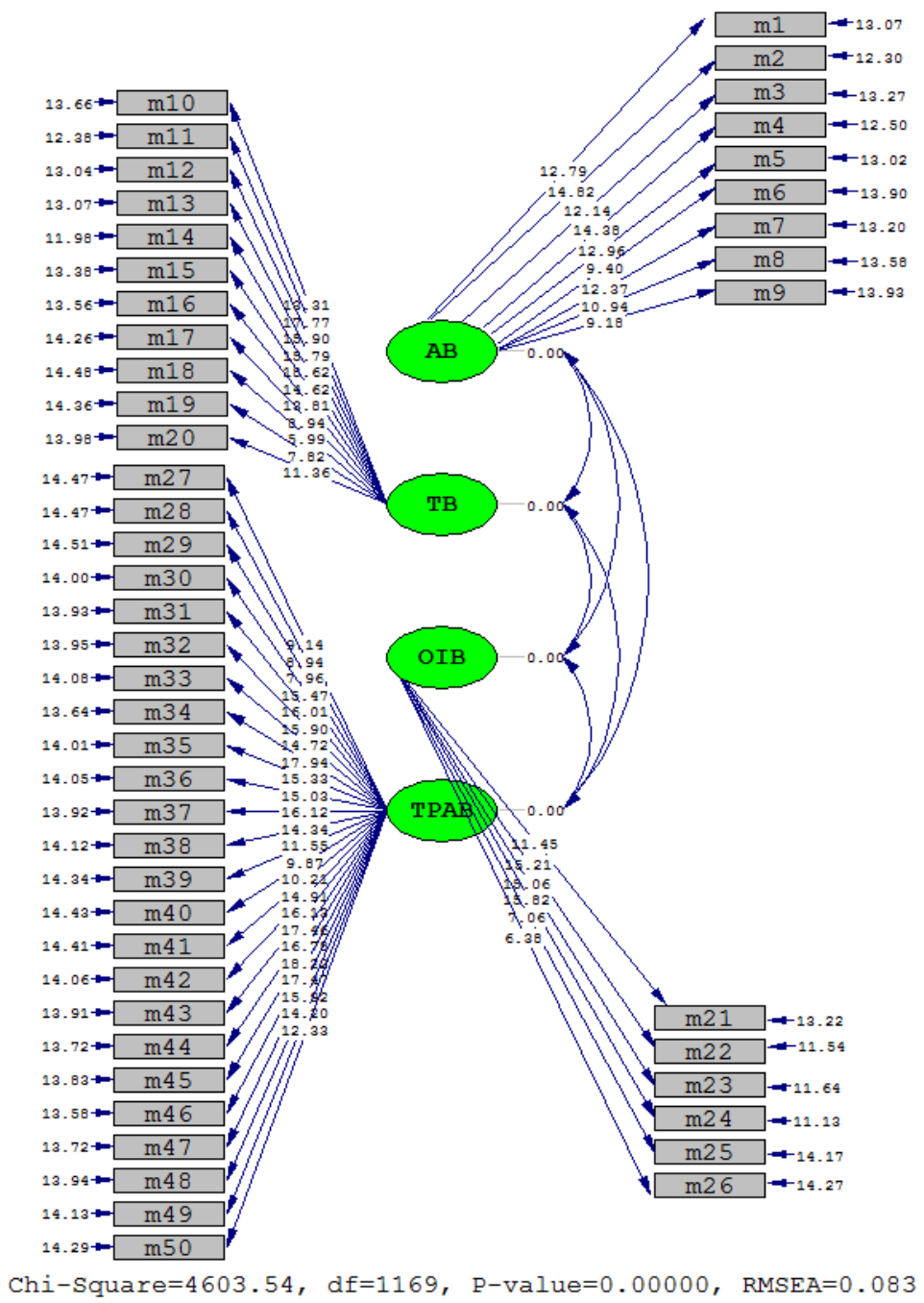

Şekil 2. Doğrulayıcı Faktör Analizi Diyagramı (t-değerleri)

Tablo 4. Düzeltme Önerileri

\begin{tabular}{|c|c|c|}
\hline Değişkenler & $\begin{array}{l}\chi^{29} \text { 'deki } \\
\text { Düșüsş }\end{array}$ & Maddeler \\
\hline $\begin{array}{l}\text { Madde } 28 \text { ile } \\
\text { Madde } 29\end{array}$ & 200.6 & $\begin{array}{l}\text { 28. Öğretmenim konuyu öğrenmemde ortaya çıkabilecek problemleri } \\
\text { incelemek amacıyla online tartısma forumlarını kullanır. } \\
\text { 29. Öğretmenim sorularımı cevaplamak amacıyla online tartışma forumlarını } \\
\text { kullanır. }\end{array}$ \\
\hline $\begin{array}{l}\text { Madde } 40 \text { ile } \\
\text { Madde } 41\end{array}$ & 185.6 & $\begin{array}{l}\text { 40. Öğretmenim akranlarımla uzaktan iletişim kurmamı sağlayan bilgi ve } \\
\text { iletişim teknolojilerini kullanır. } \\
\text { 41. Öğretmenim diğer öğretmenler ve konunun uzmanları ile uzaktan iletişim } \\
\text { kurmamı sağlayan bilgi ve iletişim teknolojilerini kullanır. }\end{array}$ \\
\hline $\begin{array}{l}\text { Madde } 30 \text { ile } \\
\text { Madde } 31\end{array}$ & 127.1 & $\begin{array}{l}\text { 30. Öğretmenim soyut kavramları öğretmek amacıyla görselleri kullanır. } \\
\text { 31. Öğretmenim soyut kavramları ögretmek amacıyla videoları kullanır. }\end{array}$ \\
\hline $\begin{array}{l}\text { Madde } 7 \text { ile } \\
\text { Teknolojik Bilgi }\end{array}$ & 97.1 & 7. Öğretmenim dersin konusu ile teknoloji arasındaki ilişkiyi bilir. \\
\hline
\end{tabular}




\section{Güvenirliğe İlişkin Bulgular}

Türkçeye uyarlanan "öğretim elemanlarının teknoloji destekli sınıflardaki yeterliklerine ilişkin öğrenci algıları ölçeği”nin güvenirliğini incelemek amacıyla yapılan iç tutarlılık analizleri sonucunda ölçeğin Cronbach alfa güvenirlik katsayısı 0.945 olarak hesaplanmıştır. Ölçeğin her bir alt boyutu için Cronbach alfa güvenirlik katsayıları ise sırasıyla; Alan Bilgisi (AB) alt boyutu için 0.81, Teknolojik Bilgi (TB) alt boyutu için 0.85, Öğrenmeye İlişkin Bilgi (ÖIB) alt boyutu için 0.73 ve Teknolojik Pedagojik Alan Bilgisi (TPAB) alt boyutu için 0.94 olarak hesaplanmıştır. Ayrıca, tüm ölçek için Spearman Brown güvenirlik katsayısı 0.742 ve Guttmann iki yarı güvenirlik katsayısı 0.725 olarak bulunmuştur. Bu sonuçlar, Türkçeye uyarlanan ölçeğin iç tutarlığının yüksek olduğunu göstermektedir. Spearman Brown güvenirlik katsayısı ve Guttmann iki yarı güvenirlik katsayısının Cronbach alfa katsayısından nispetten düşük olması, ölçeğin ikinci yarısındaki maddelerin (26-50. maddelerin) neredeyse hepsinin ölçeğin son alt boyutunda (TPAB alt boyutunda) yer almasından kaynaklanıyor olabilir.

\section{Tartışma ve Sonuç}

Bu araştırmada, Shih ve Chuang (2013) tarafından geliştirilen "Öğretim Elemanlarının Teknoloji Destekli Sınıflardaki Bilgilerine İlişkin Öğrenci Algıları Ölçeği”nin Türkçeye uyarlaması yapılmıştır. Uyarlanan ölçeğin yapı geçerliği ve güvenirliği gibi psikometrik özellikleri, ölçeğin 430 lisans öğrencisine uygulanması sonucunda elde edilen veriler ile test edilmiştir. Yapılan KMO ve Bartlett testlerinin sonuçları çalışma grubundan toplanan verinin uyarlanan ölçeğin yapı geçerliğini ve güvenirliğini test etmek için uygun olduğunu göstermiştir. Yapı geçerliğini test etmek amacıyla yapılan doğrulayıcı faktör analizi sonucunda ulaşılan uyum iyiliği indekslerinin değerleri, çalışma grubundan elde edilen veriler ile uyarlana ölçeğin 4 faktörlü yapısının (AB, TB, ÖIB, TPAB) iyi uyum gösterdiğini ortaya koymuştur. Bir başka ifade ile bu araştırmada, orijinal ölçeğin 4 faktörlü yapısı Türkiye örnekleminde doğrulanmıştır. Ayrıca, DFA sonucunda elde edilen $t$ değerleri, uyarlanan ölçeğin tüm alt boyutları ile bu alt boyutlara ait maddeler arasındaki iliş̧kilerin anlamlı olduğunu göstermiştir. Türkçeye uyarlanan ölçeğin güvenirliğini incelemek amacıyla yapılan iç tutarlılık analizleri, ölçeğin iç tutarlı̆̆ının orijinal ölçekte olduğu gibi yüksek olduğunu ortaya koymuştur. DFA ve iç tutarlılık analiz sonuçları, orijinal ölçeğin ortaya koyduğu modelin Türkiye'de amacı doğrultusunda kullanılması halinde geçerli ve güvenilir olduğuna işaret etmektedir. Bu araştırmayla, Türkçeye uyarlanan ölçeğin çalışma grubunda da geliştirildiği kültürdekine benzer şekilde çalıştı̆̆ tespit edilmiştir.

Öğretimin kalitesini, öğrencilerin öğretim hakkındaki düşünceleriyle ve öğrenci kazanımlarının yeterliliğiyle ölçmek mümkündür (Knight \& Waxman, 1991; Tuan ve diğerleri, 2000). Bu doğrultuda, öğrenci gözüyle öğretimin kalitesini ve öğretmeninin bilgisini sorgulayan ölçekler büyük öneme sahiptir. Teknolojinin öğretim ortamında yaygın olarak kullanılmaya başlandığı günümüzde, teknoloji destekli öğretimin kalitesini ve öğretmenin teknolojik pedagojik alan bilgisini öğrenci algılarıyla belirleyecek ölçme araçlarına ihtiyaç duyulmaktadır. Bu anlamda, bu araştırmayla öğretim elemanlarının teknoloji destekli sınıflardaki bilgilerini öğrenci algılarıyla belirleyen geçerliği ve güvenirliği sağlanmış Türkçe bir ölçek ortaya konmuştur. Son zamanlarda, TPAB'ın öğretmen yeterlik alanları içerisine dahil edilmesi (MEB, 2013), öğretmenlere TPAB'ı kazandırmayı amaçlayan eğitim uygulamaları ile ilgili projelere destek verilmesi (Canbazoğlu Bilici, 2013) ve öğretim ortamlarında öğretmenlerin TPAB düzeylerini konu alan araştırmaların yapılması (Allan ve diğerleri, 2010; Canbazoğlu Bilici, 2012; Lee \& Tsai, 2010; Polly, 2011) bu araştırmayla Türkiye şartlarında uygulanabilir bir ölçeğin literatüre kazandırılmasının önemine işaret etmektedir. Ölçeğin, öğretimde kullanımı itibariyle yeni sayılabilecek teknolojileri ve uygulamalarını (online forum, blog, podcast, sanal müze, video konferans, facebook, vb.) ve TPAB'ı içermesi günümüz koşullarında yenilikçi ve katkı sağlayıcı bir yapısının olduğunu göstermektedir.

$\mathrm{Bu}$ çalışma kapsamında Türkçeye uyarlaması gerçekleştirilen ölçek, öğretim elemanlarının teknoloji destekli sınıflardaki yeterliklerine ilişkin öğrenci algılarının belirlenmesi amacıyla eğitim araştırmacıları tarafından kullanılabilir. Ölçeğin kullanılmasıyla öğretim elemanlarının öğretme kalitesi hakkında araştırmacılar fikir sahibi olabilir. Bu fikirler öğretimin kalitesini artıracak, işlenebilir yeni fikirlerin ortaya çıkmasına imkân verebilir. Günümüz koşullarına uygun TPAB içeren yeni öğretim modellerinin veya yeni öğretim yöntem ve stratejilerinin geliştirilmesi, orta ve yükseköğretim düzeyinde TPAB temelli yeni öğretim programlarının geliştirilmesi bu yeni fikirlere örnek olarak gösterilebilir. Ölçeğin, orta öğretim seviyesinde kullanılabilmesi için ilgili gruba uygunluğu incelenebilir. Ancak ölçek maddeleri içerisinde adı geçen teknolojik ve pedagojik kökenli bazı spesifik terimlerin ölçek uygulanmadan önce öğrencilere açıklanması faydalı olacaktır. Bu sayede, ölçek maddelerinde adı geçen 
teknolojilerin orta öğretim seviyesindeki okullarda bulunması durumunda, ölçeğin veri toplama aracı olarak kullanılmasıyla öğretmenlerinin teknoloji destekli sınıflardaki yeterliklerime ilişkin lise öğrencilerinin algıları tespit edilebilir.

Sonuç olarak; bu araştırmanın sonucunda Shih ve Chuang (2013) tarafından geliştirilen "Öğretim Elemanlarının Teknoloji Destekli Sınıflardaki Bilgilerine İlişkin Öğrenci Algıları Ölçeği”nin Türkçeye uyarlaması gerçekleştirilmiştir. Uyarlanan ölçeğin Türkiye örnekleminde geçerli ve güvenilir olduğu tespit edilmiş, bunun neticesinde Türkiye şartlarında uygulanabilir olduğu belirlenmiştir. Uyarlama çalışmasının bir üniversitenin lisans öğrencileri ile sınırlı tutulması, bir sınırlılık olarak görülebilir. Farklı örneklem grupları ile yürütülecek araştırmalarla Türkçeye uyarlanan ölçeğin geçerlik ve güvenirliğine ilişkin yeni kanıtlar sunulabilir. 


\section{References}

Akgün, F. (2013). Öğretmen adaylarının web pedagojik içerik bilgileri ve öğretmen öz-yeterlik algıları ile ilişkisi [Preservice teachers' web pedagogical content knowledge and relationship between teachers' perceptions of self Efficacy]. Trakya Üniversitesi Ĕ̆itim Fakültesi Dergisi, 3(1), 48-58.

Akın, A., Uysal, R., \& Çitemel, N. (2013). Çocukluk deneyimleri ölçeğinin Türkçeye uyarlanması [The validity and reliability of Turkish version of the early life experiences scale]. Kastamonu Ĕgitim Dergisi, 21(4), 1541-1550.

Aksoy, H. H. (2003). Eğitim kurumlarında teknoloji kullanımı ve etkilerine ilişkin bir çözümleme [An analysis of the use and effects of technology in educational institutions]. Eğitim Bilim Toplum, 1(4), 4-23.

Allan, W. C., Erickson, J. L., Brookhouse, P., \& Johnson, J. L. (2010). Teacher professional development through a collaborative curriculum project - An example of TPACK in Maine. TechTrends, 54(6), 36-43.

Angeli, C., \& Valanides, N. (2005). Preservice elementary teachers as information and communication technology designers: An instructional systems design model based on an expanded view of pedagogical content knowledge. Journal of Computer Assisted Learning, 21(4), 292-302.

Angeli, C., \& Valanides, N. (2009). Epistemological and methodological issues for the conceptualization, development, and assessment of ICT-TPCK: Advances in technological pedagogical content knowledge (TPCK). Computers \& Education, 52(1), 154-168.

Archambault, L., \& Crippen, K. (2009). Examining TPACK among K-12 online distance educators in the United States. Contemporary Issues in Technology and Teacher Education, 9(1), 71-88.

Arkorful, V., \& Abaidoo, N. (2014). The role of e-learning, the advantages and disadvantages of its adoption in higher education. International Journal of Education and Research, 2(12), 397-410.

Bennett, S., Bishop, A., Dalgarno, B., Waycott, J., \& Kennedy, G. (2012). Implementing Web 2.0 technologies in higher education: A collective case study. Computers \& Education, 59(2), 524-534.

Brown, T.A. (2006). Confirmatory factor analysis for applied research. New York: The Guilford Press.

Çakır, H. (2013). Use of blogs in pre-service teacher education to improve student engagement. Computers \& Education, 68, 244-252.

Campbell, T., \& Abd-Hamid, N. H. (2013). Technology use in science instruction (TUSI): Aligning the integration of technology in science instruction in ways supportive of science education reform. Journal of Science Education and Technology, 22(4), 572-588.

Canbazoğlu Bilici, S. (2012). Fen bilgisi ögretmen adaylarının teknolojik pedagojik alan bilgisi ve özyeterlikleri [The pre-service science teachers' technological pedagogical content knowledge and their self-efficacy]. Unpublished $\mathrm{PhD}$ thesis, Gazi University, Institute of Educational Sciences, Ankara.

Canbazoğlu Bilici, S. (2013). Fen ve teknoloji öğretmenlerine teknolojik pedagojik alan bilgisi kazandırma amaçlı eğitim uygulamalar [Instructional practices of technological pedagogical content knowledge for preservice science teachers]. TÜBİTAK 4005 Programı: Bilim ve Toplum Yenilikçi Eğitim Uygulamaları. Proje No: 113B254. [http://www.tubitak.gov.tr/tr/duyuru/4005-yenilikci-egitim-uygulamalari-cagrisisonuclandi]. Accessed 13 September 2013.

Chen, Y. H., \& Jang, S.-J. (2014). Interrelationship between stages of concern and technological, pedagogical, and content knowledge: A study on Taiwanese senior high school in-service teachers. Computers in Human Behavior, 32, 79-91.

Comrey, A. L., \& Lee, H. B. (1992). A first course in factor analysis (2nd ed.). Hlilsdale, NJ: Lawrence Erlbaum Associates. 
Deniz, K. Z. (2007). Psikolojik ölçme aracı uyarlama [The Adaptation of Psychological Scales]. Ankara Üniversitesi Eğitim Bilimleri Fakültesi Dergisi, 40(1), 1-16.

Hao, Y. (2016). The development of pre-service teachers' knowledge: A contemplative approach. Computers in Human Behavior, 60, 155-164.

Hew, K. F. (2016). Promoting engagement in online courses: What strategies can we learn from three highly rated MOOCS. British Journal of Educational Technology, 47(2), 320-341.

Hooper, D., Coughlan, J., \& Mullen, M. R. (2008). Structural equation modelling: Guidelines for determining model fit. The Electronic Journal of Business Research Methods, 6(1), 53-60.

Hsu, C.-K., Hwang, G.-J., Chuang, C.-W., \& Chang, C.-K. (2012). Effects on learners' performance of using selected and open network resources in a problem-based learning activity. British Journal of Educational Technology, 43(4), 606-623.

Hu, L., \& Bentler, P. M. (1995). Evaluating model fit. In R. H. Hoyle (Ed.), Structural equation modeling: Concepts, issues and applications (pp. 76-88). London: Sage Publications.

Hu, L., \& Bentler, P. M. (1999). Cutoff criteria for fit indexes in covariance structure analysis: Conventional criteria versus new alternatives. Structural Equation Modeling: A Multidisciplinary Journal, 6(1), 1-55.

George, D., \& Mallery, P. (2003). SPSS for Windows step by step: A simple guide and reference. 11.0 Update (4th ed.). Boston: Allyn and Bacon.

Graham, C. R., Burgoyne, N., Cantrell, P., Smith, L., Clair, L. S., \& Harris, R. (2009). TPACK development in science teaching: Measuring the TPACK confidence of inservice science teachers. TechTrends, 53(5), 7079.

Gülbahar, Y., \& Büyüköztürk, Ş. (2008). Değerlendirme tercihleri ölçeğinin Türkçeye uyarlanması [Adaptation of assessment preferences inventory to Turkish]. Hacettepe Üniversitesi Eğitim Fakültesi Dergisi, 35, 148161.

Jöreskog, K. G., \& Sörbom, D. (1993). LISREL 8: Structural equation modeling with the SIMPLIS command language. Lincolnwood: Scientific Software International, Inc.

Karadeniz, Ş., Büyüköztürk, Ş., Akgün, Ö. E., Çakmak, E. K., \& Demirel, F. (2008). The Turkish adaptation study of motivated strategies for learning questionnaire (MSLQ) for 12-18 year old children: Results of confirmatory factor analysis. The Turkish Online Journal of Educational Technology, 7(4), 108-117.

Kaya, S., \& Dağ, F. (2013). Sınıf öğretmenlerine yönelik teknolojik pedagojik içerik bilgisi ölçeği’nin Türkçe’ye uyarlanması [Turkish adaptation of technological pedagogical content knowledge survey for elementary teachers]. Kuram ve Uygulamada Eğitim Bilimleri, 13(1), 291-306.

Kaya, Z., Kaya, O. N., \& Emre, İ. (2013). Teknolojik pedagojik alan bilgisi (TPAB) ölçeği’nin Türkçeye uyarlanması [Adaptation of technological pedagogical content knowledge scale to Turkish]. Kuram ve Uygulamada Eğitim Bilimleri, 13(4), 2355-2377.

Kelloway, E. K. (1998). Using LISREL for structural equation modeling: A researcher's guide. California: Sage Publications.

Knight, S. L., \& Waxman, H. C. (1991). Students' cognition and classroom instruction. In H. C. Waxman, \& H. J. Walberg (Eds.), Effective teaching: Current research (pp. 239-255). Berkeley, CA: McCutchan.

Koehler, M. J., \& Mishra, P. (2012). Using the TPACK image. http://tpack.org/. (Accessed 14 December 2015).

Koehler, M. J., Mishra, P., \& Yahya, K. (2007). Tracing the development of teacher knowledge in a design seminar: Integrating content, pedagogy and technology. Computers \& Education, 49(3), 740-762.

Lee, D. Y. (2011). Korean and foreign students' perceptions of the teacher's role in a multicultural online learning environment in Korea. Educational Technology Research and Development, 59(6), 913-935. 
Lee, M.-H., \& Tsai, C.-C. (2010). Exploring teachers' perceived self-efficacy and technological pedagogical content knowledge with respect to educational use of the World Wide Web. Instructional Science, 38(1), $1-21$.

Maindal, H. T., Sokolowski, I., \& Vedsted, P. (2010). Adaptation, data quality and confirmatory factor analysis of the Danish version of the PACIC questionnaire. European Journal of Public Health, 22(1), 31-36.

Manca, S., \& Ranieri, M. (2016). Facebook and the others. Potentials and obstacles of social media for teaching in higher education. Computers \& Education, 95, 216-230.

Merchant, Z., Goetz, E.T., Cifuentes, L., Keeney-Kennicutt, W., \& Davis, T. J. (2014). Effectiveness of virtual reality-based instruction on students' learning outcomes in K-12 and higher education: A meta-analysis. Computers \& Education, 70, 29-40.

MEB [Milli Eğitim Bakanlığı] (11 Mayıs 2013). Ulusal öğretmen strateji belgesi taslağl [Draft of national strategy document for teacher]. [http://www.memurlar.net/haber/373146]. Accessed 18 February 2017.

Mishra, P., \& Koehler, M. J. (2006). Technological pedagogical content knowledge: A framework for teacher knowledge. Teachers College Record, 108(6), 1017-1054.

Niess, M. L. (2005). Preparing teachers to teach science and mathematics with technology: Developing a technology pedagogical content knowledge. Teaching and Teacher Education, 21(5), 509-523.

Öztürk, E. (2013). Sınıf öğretmeni adaylarının teknolojik pedagojik alan bilgilerinin bazı değişkenler açısından değerlendirilmesi [Prospective classroom teachers' technological pedagogical content knowledge assessment in terms of some Variables]. Uşak Üniversitesi Sosyal Bilimler Dergisi, 6(2), 223-228.

Öztürk, E., \& Horzum, M. B. (2011). Teknolojik pedagojik içerik bilgisi ölçeği’nin Türkçeye uyarlaması [Adaptation of technological pedagogical content knowledge scale to Turkish]. Ahi Evran Üniversitesi Eğitim Fakültesi Dergisi, 12(3), 255-278.

Pamuk, S. (2012). Understanding preservice teachers' technology use through TPACK framework. Journal of Computer Assisted Learning, 28(5), 425-439.

Pekdağ, B. (2010). Kimya öğreniminde alternatif yollar: Animasyon, simülasyon, video ve multimedya ile ögrenme [Alternative tools for chemistry education: animation, simulation, video and multimedia]. Türk Fen Eğitimi Dergisi, 7(2), 79-110.

Pekdağ, B. (2015). Deney videolart ile kimya öğretimi [Chemistry teaching with experimental videos]. In A. Ayas \& M. Sözbilir, Kimya öğretimi: Öğretmen eğitimcileri, öğretmenler ve öğretmen adayları için iyi uygulama örnekleri (ss. 653-678). Ankara: Pegem Akademi.

Polly, D. (2011). Examining teachers' enactment of technological pedagogical and content knowledge (TPACK) in their mathematics teaching after technology integration professional development. Journal of Computers in Mathematics and Science Teaching, 30(1), 37-59.

Preston, J. P, Wiebe, S., Gabriel, M., McAuley, A., Campbell, B., \& MacDonald, R. (2015). Benefits and challenges of technology in high schools: A voice from educational leaders with a Freire Echo. Interchange, 46(2), 169-185.

Rabah, J. (2015). Benefits and challenges of information and communication technologies (ICT) integration in Québec English schools. The Turkish Online Journal of Educational Technology, 14(2), 24-31.

Schmidt, D. A., Baran, E., Thompson, A. D., Mishra, P., Koehler, M. J., \& Shin, T. S. (2009). Technological pedagogical content knowledge (TPACK): The development and validation of an assessment instrument for preservice teachers. Journal of Research on Technology in Education, 42(2), 123-149.

Schumacker, R. E., \& Lomax, R. G. (2004). A beginner's guide to structural equation modeling (2nd ed.). Mahwah, NJ: Lawrence Erlbaum Associates.

Shih, C.-L., \& Chuang, H,-H. (2013). The development and validation of an instrument for assessing college students' perceptions of faculty knowledge in technology-supported class environments. Computers \& Education, 63, 109-118. 
Shulman, L. S. (1987). Knowledge and teaching: Foundations of the new reform. Harvard Educational Review, 57(1), 1-22.

Sümer, N. (2000). Yapısal eşitlik modelleri: Temel kavramlar ve örnek uygulamalar [Structural equation models: Basic concepts and practices]. Türk Psikoloji Yazllarl, 3(6), 49-74.

Şencan, H. (2005). Sosyal ve davranışsal ölçümlerde güvenilirlik ve geçerlilik [Reliability and validity in social and behavioral measures]. Ankara: Seçkin Yayıncılık.

Tabachnick, B. G., \& Fidell, L. S. (2001). Using multivariate statistics (4 ${ }^{\text {th }}$ ed.). MA: Allyn and Bacon.

Tavşanc1l, E. (2010). Tutumların ölçülmesi ve SPSS ile veri analizi [Measuring attitudes and data analysis with SPSS ] (4 ${ }^{\text {th }}$ ed.). Ankara: Nobel Akademik Yayıncılik.

TED [Türk Eğitim Derneği] (2009). Öğretmen yeterlikleri özet rapor: Ö̆gretmene yatırım, geleceğe atılım [Teacher competencies summary report: Investment in teacher, breakthrough in the future]. Ankara: Adım Okan Matbaacılık.

Timur, B., \& Taşar, M. F. (2011). Teknolojik Pedagojik Alan Bilgisi Öz Güven Ölçeğinin (TPABÖGÖ) Türkçe’ye Uyarlanmas1 [The adaptation of the technological pedagogical content knowledge confidence survey into Turkish]. Gaziantep Üniversitesi Sosyal Bilimler Dergisi, 10(2), 839-856.

Tuan, H.-L., Chang, H.-P., Wang, K.-H., \& Treagust, D. F. (2000). The development of an instrument for assessing students' perceptions of teachers' knowledge. International Journal of Science Education, 22(4), 385-398.

Tüzün, H., \& Özdinç, F. (2016). The effects of 3D multi-user virtual environments on freshmen university students' conceptual and spatial learning and presence in departmental orientation. Computers \& Education, 94, 228-240.

Wright, B. D., \& Stone, M. H. (1999). Measurement essentials (2nd ed.). Wilmington, DE: Wide Range, Inc.

Yılmaz, M., Gürçay, D., \& Ekici, G. (2007). Akademik özyeterlik ölçeğinin Türkçe’ye uyarlanması [Adaptation of the academic self-efficacy scale to Turkish]. Hacettepe Üniversitesi Eğitim Fakültesi Dergisi, 33, 253259.

Yılmaz, M., Köseoğlu, P., Gerçek, C., \& Soran, H. (2004). Yabancı dilde hazırlanan bir öğretmen öz-yeterlik ölçeğinin Türkçe'ye uyarlanması [Adaptation of a teacher self-efficacy scale to Turkish]. Hacettepe Üniversitesi Eğitim Fakültesi Dergisi, 27, 260-267.

Yu, F.-Y., \& Wu, C.-P. (2016). The effects of an online student-constructed test strategy on knowledge construction. Computers \& Education, 94, 89-101. 


\section{Appendix}

\section{Öğretim Elemanlarının Teknoloji Destekli Sınıflardaki Bilgilerine İlişkin Öğrenci Algıları Ölçeği}

Alan Bilgisi (AB) [Subject Matter Knowledge-SMK]

1. Öğretmenim anlattığı konuyu iyi bilir.

2. Öğretmenim konunun organizasyonunu iyi yapar.

3. Öğretmenim konunun kuramsal temellerinin tarihi gelişimini bilir.

4. Öğretmenim derste öğretilen kavramların kapsam ve derinliğine iyi karar verir.

5. Öğretmenim derste öğretilen kavramların sıralamasını iyi planlar.

6. Öğretmenim ders konularının gündelik yaşamda nasıl uygulandığı konusunda örnekler verir.

7. Öğretmenim dersin konusu ile teknoloji arasındaki ilişkiyi bilir.

8. Öğretmenim dersin konusu ile toplum arasındaki ilişkileri açıklar.

9. Öğretmenim derste öğrettikleriyle ilgili sorularıma cevap verir.

Teknolojik Bilgi (TB) [Technological Knowledge-TK]

10. Öğretmenim bilgisayar, internet ve cep telefonu gibi çeşitli teknolojik ürünler ve uygulamaları hakkında bilgi sahibidir.

11. Öğretmenim öğretimde teknolojiyi kullanma becerisine sahiptir.

12. Öğretmenim yeni ve önemli teknolojik gelişmeleri takip eder.

13. Öğretmenim sınıfta teknolojiyi sıklıkla kullanır.

14. Öğretmenim sınıfta teknolojiyi rahatlıkla kullanır.

15. Öğretmenim donanımla ilgili teknik problemleri çözer.

16. Öğretmenim bilgisayar yazılımlarıyla ilgili sorunları çözmeyi (programların kurulması, uygun eklentilerin yüklenmesi vb.) başarır.

17. Öğretmenim dersin içeriğini sunmak amacıyla PowerPoint’i ve benzer diğer programları kullanır.

18. Ögretmenim blog, facebook ve podcast gibi web 2.0 teknolojilerini sınıfta kullanır.

19. Öğretmenim kendi öğretim web sitesini kurar.

20. Öğretmenim ders için elektronik materyaller (video, sunum, eğitim yazılımı vb) geliştirir.

Öğrenmeye İlişkin Bilgi (ÖİB) [Knowledge of Students’ Understanding-KSU]

21. Öğretmenim ön bilgilerim hakkında bilgiye sahiptir.

22. Öğretmenim konuyu öğrenmede yaşadığım zorlukları ve kavram yanılgılarımı fark eder.

23. Öğretmenim konuyu ne kadar anladığımı belirlemek amacıyla uygun sorular sorar.

24. Öğretmenim konuyu ne kadar anladığımı ölçmek amacıyla farklı değerlendirme yöntemleri kullanır.

25. Öğretmenim konuyu pekiştirmemi sağlayan ödevler verir.

26. Öğretmenim öğrenme durumumu belirlememe yardımcı olan testler verir.

Teknolojik Pedagojik Alan Bilgisi (TPAB) [Technological Pedagogical Content Knowledge-TPACK]

27. Öğretmenim öğrenmemi değerlendirmek amacıyla online portfolyo kullanır.

28. Öğretmenim konuyu öğrenmemde ortaya çıkabilecek problemleri incelemek amacıyla online tartışma forumlarını kullanır.

29. Öğretmenim sorularımı cevaplamak amacıyla online tartışma forumlarını kullanır.

30. Öğretmenim soyut kavramları öğretmek amacıyla görselleri kullanır.

31. Öğretmenim soyut kavramları öğretmek amacıyla videoları kullanır.

32. Öğretmenim karmaşık konuları öğretmek amacıyla animasyonları kullanır.

33. Öğretmenim karmaşık konuları öğretmek amacıyla bilgisayar simülasyonları kullanır.

34. Öğretmenim konuları daha kolay anlamama yardımcı olmak amacıyla farklı türde medyaları birlikte kullanır.

35. Öğretmenim konuyu anlamama yardımcı olmak amacıyla farklı sunum teknolojilerini kullanır.

36. Öğretmenim konuyu daha kolay anlamama yardımcı olmak amacıyla multimedya (çoklu ortam) etkileşimini kullanır.

37. Öğretmenim konuyu daha kolay anlamama yardımcı olmak amacıyla videoları kullanır.

38. Öğretmenim konuyu daha kolay anlamama yardımcı olmak amacıyla verileri, diyagramları ve modelleri göstermek için bilgisayar simülasyonları kullanır. 
39. Öğretmenim ders konusunu araştırmama imkan veren sanal laboratuvar, sanal müze veya elektronik arşiv gibi teknolojileri kullanır.

40. Öğretmenim akranlarımla uzaktan iletişim kurmamı sağlayan bilgi ve iletişim teknolojilerini kullanır.

41. Öğretmenim diğer öğretmenler ve konunun uzmanları ile uzaktan iletişim kurmamı sağlayan bilgi ve iletişim teknolojilerini kullanır.

42. Öğretmenim akranlarımla işbirliği içinde çalışmama imkan veren bilgi ve iletişim teknolojilerini kullanır.

43. Öğretmenim öğrencilerin bireysel ihtiyaçlarını dikkate alan teknolojileri kullanır.

44. Öğretmenim ders konularına uygun olan teknolojileri seçer.

45. Öğretmenim konunun öğretimine online materyalleri dahil eder.

46. Öğretmenim ders konularını öğretmek amacıyla uygun teknolojileri kullanır.

47. Öğretmenim görüşlerimi ifade etme ve arkadaşlarımla etkileşimde bulunma olanağı sağlayan uygun teknolojileri (sosyal medya, online forumlar, bloglar vb.) kullanır.

48. Öğretmenim dersin konusu ile ilgili kavram yanılgılarımı fark etmeme yardımcı olmak amacıyla uygun teknolojileri (sosyal medya, online forumlar, bloglar vb.) kullanır.

49. Öğretmenim sorularımı cevaplamak amacıyla uygun teknolojileri (online forumlar, bloglar, öğretimsel web siteleri vb.) kullanır.

50. Öğretmenim öğrendiklerimi göstermem için teknolojiyi kullanmama firsat verir. 